\title{
Diet and mobility during the Christian conquest of Iberia: The multi-isotopic investigation of a 12th-13th century military order in Évora, Portugal
}

\author{
Rebecca Anne MacRoberts ${ }^{\mathrm{a}}$, Cristina Maria Barrocas Dias ${ }^{\mathrm{a}, \mathrm{b}}$, Teresa Matos Fernandes ${ }^{\mathrm{c}, \mathrm{d}}$, \\ Ana Luisa Santos ${ }^{c}$, Claudia Umbelino ${ }^{\mathrm{c}, \mathrm{e}}$, Ana Gonçalves ${ }^{\mathrm{f}}$, Jose Santos ${ }^{\mathrm{g}}$, Sara Ribeiro ${ }^{\mathrm{g}}$, \\ Bernd R. Schöne ${ }^{\mathrm{h}}$, Filomena Barros ${ }^{\mathrm{i}}$, Fernando Correia ${ }^{\mathrm{i}}$, Herminia Vasconcelos Vilar ${ }^{\mathrm{i}}$, \\ Anne-France Maurer ${ }^{\mathrm{a}, *}$
}

${ }^{a}$ HERCULES Laboratory, University of Évora, Largo Marquês de Marialva 8, 7000-809 Évora, Portugal

${ }^{\mathrm{b}}$ School of Technology Sciences, Department of Chemistry, University of Évora, Rua Romão Ramalho 59, 7000-671 Évora, Portugal

${ }^{\mathrm{c}}$ Research Centre for Anthropology and Health (CIAS), University of Coimbra, Apartado 3046, 3001-401 Coimbra, Portugal

${ }^{\mathrm{d}}$ School of Technology Sciences, Department of Biology, University of Évora, Apartado 94, 7002-554 Évora, Portugal

${ }^{\mathrm{e}}$ Department of Life Sciences, Faculty of Sciences and Technology, University of Coimbra, Calçada Martim de Freitas, 3000-456 Coimbra, Portugal

${ }^{\mathrm{f}}$ Arkhaios, Evora, Portugal

${ }^{g}$ Geobiotec, Department of Geosciences, University of Aveiro, Campus de Santiago, 3810-193 Aveiro, Portugal

${ }^{\mathrm{h}}$ Institute of Geosciences, University of Mainz, Johann-Joachim-Becher-Weg 21, 55128 Mainz, Germany

${ }^{\mathrm{i}}$ Universidade de Évora - Escola de Ciências Sociais - CIDEHUS, Evora, Portugal

\section{A R T I C L E IN F O}

\section{Keywords:}

Diet mobility

Isotopes

Medieval

Portugal

\begin{abstract}
A B S T R A C T
The Kingdom of Portugal was established with the help of military-monastic orders, which provided important defence against Muslim armies during the 12th-13th century Christian conquest. While historical sources document the main events of this period, this research seeks to elucidate individual lifestyles and movement, aspects typically absent from written records. A multi-isotopic approach was used on skeletal material from eight Christian and two Muslim burials from Évora, Portugal (11th-13th centuries). Anthropological and archaeological evidence suggests the Christian adults belonged to the Évora Militia, which we seek to confirm through the reconstructed diet and mobility of these individuals. Stable carbon, nitrogen and sulphur isotopes were measured in bone collagen, and radiogenic strontium, carbonate stable oxygen and apatite stable carbon isotopes were measured in tooth enamel. Results of the stable oxygen and radiogenic strontium isotopes indicated diverse origins of the Christian population, while at least one individual was local. The Muslim adult was local, as anticipated. The $\delta^{13} \mathrm{C}_{\text {en }}$ (enamel) values provide evidence of childhood consumption of different cereals $\left(\mathrm{C}_{3}\right.$ and $\mathrm{C}_{4}$ ), possibly linked to social status. The $\delta^{13} \mathrm{C}_{\mathrm{col}}$ (bone collagen) human values indicated mostly $\mathrm{C}_{3}$ diets with varying inputs of $\mathrm{C}_{4}$, while $\delta^{15} \mathrm{~N}$ reflected high protein intake overall. The mean diet-consumer spacing of this population was compared to other isotopic studies from Medieval Iberia and other European monastic/convent populations. A visible trend emerged in populations that likely followed religious fasting rules, including the Évora Christians. The results of this study indicate that the Order of Évora was composed of members from diverse geographic and possibly social origins, an aspect previously unclear in written sources.
\end{abstract}

\section{Introduction}

Stable isotope studies as tools to reconstruct the diet and/or mobility of populations have been used increasingly in archaeological research elsewhere in Iberia (Quiros Castillo, 2013; Alexander et al., 2015; Jiménez-Brobeil et al., 2016; Guede et al., 2017a, 2017b; Lubritto et al., 2017; MacKinnon et al., 2019). In Portugal, only a few relatively recent studies (Luxton, 2015; Curto et al., 2018; Toso et al., 2019) applied stable isotopes to reconstruct the way of life of medieval populations. This approach is used here to investigate the Christian conquest of the Iberian Peninsula, which was a period of significant cultural, religious and ideological change. During the 12th and 13th centuries, military monastic orders were established and expanded throughout Spain and Portugal to capture cities and towns from Islamic control and protect them against recurring attacks (Faria, 2001; Farwell and Molleson, 1993). A series of excavations in the museum cellars in

\footnotetext{
* Corresponding author.

E-mail address: annefrance.maurer@gmail.com (A.-F. Maurer).
} 


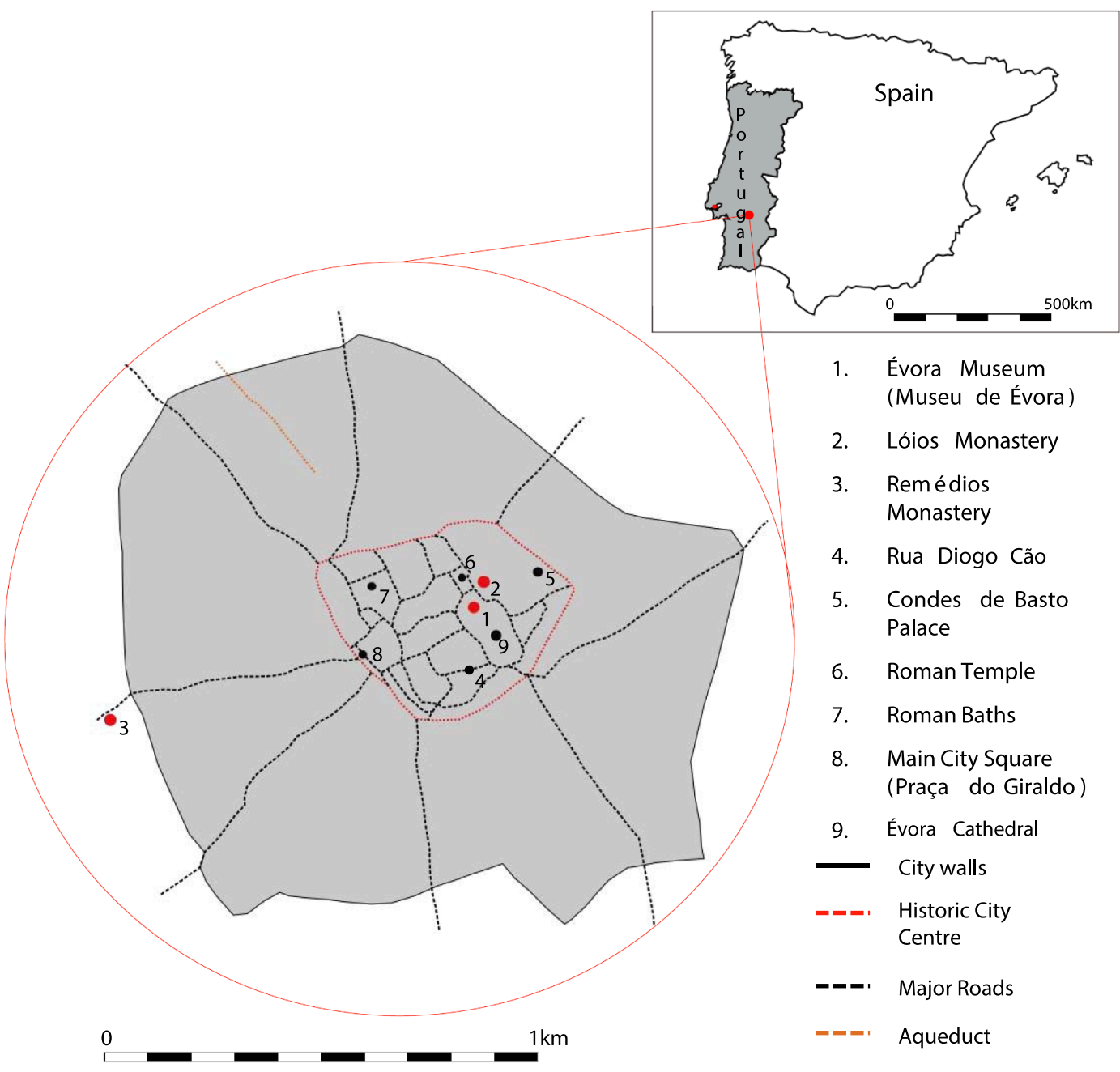

Fig. 1. Location map of Évora showing the proveniences of the samples.

Évora, Portugal (illustrated in Fig. 1) in the 1990s and 2000s recovered graves from the Islamic Period (8th-12th centuries) and several Christian burials from during, or soon after, the conquest (12th-13th centuries). The skeletons buried as Christians can be linked, as we shall see, to the knights of the Order of Évora (or Évora Militia), a military group about whose organisation and social composition we know little, especially in the first decades of its existence (Santos and Umbelino, 1997; Santos et al., 1998; Guerra and Fernandes, 2007; Santos and Umbelino, 2007).

Using a multi-isotopic approach we intend to reconstruct dietary and mobility patterns of the individuals buried underneath the Museu de Évora in order to better understand the way of life of the individuals who participated in the conquest at the dawn of the Portuguese Kingdom.

\subsection{Historical context}

The city of Évora, in the south of Portugal, has a rich history involving dramatic shifts of political and economic importance through various periods of Roman, Visigothic and Islamic rule (Marquez, 1971; Picard, 2000; Paredes, 2001; Faria, 2001; Rei, 2005; Lay, 2009; Felipe, 2012). The latter of these lasted from the 8 th to the 12th century when the Christians conquered the city in $1165 \mathrm{CE}$, led by "Giraldo sem Pavor" (Gerald the Fearless). In the following year, Afonso I (1128-1185 CE), the first king of Portugal, integrated Évora into the kingdom. King Afonso I saw the need to establish an elite military order in the city of Évora so that it would not fall back under Islamic jurisdiction, as many other administrative centres along the Tagus had done (Barata et al., 2001; Beirante, 1995). Thus, the "Order of Évora", or "Évora Militia" was established around 1175 CE (De Oliveira, 1956; Cunha, 2009) and remained in the city until at least $1211 \mathrm{CE}$ when the knights were donated a fortress and property in Avis by King Afonso II and subsequently moved there, taking the name "Order of Avis" (Josserand, 2006; Josserand, 2017). By 1250 CE the last Islamic defenders were driven out of Portugal entirely (Cunha, 1988; Sidarus, 1997; Josserand, 2006; Lay, 2009).

The subject of the origins of this militia has divided historians. Some argue that members were a branch of the Castilian Order of Calatrava, who entered Portugal and established themselves in Évora. Others maintain they were Portuguese Benedictine monks who later aligned themselves with Calatrava, and embraced Cistercian rule (Tarouca, 1947; De Oliveira, 1956; Wolfe, 1999; Ayala, 2006; Josserand, 2006; Pizarro, 2006; Lay, 2009; Josserand, 2017). The earliest evidence of association with the Order of Calatrava is found between 1176 and 1187 CE in a papal bull that mentions the Portuguese assets of Calatrava (Ayala Martinez, 2003). There is consensus that the main members of this militia were non-local, and only arrived after the city of Évora was conquered. What remains unclear is whether the members moved as a unit from elsewhere, possibly Calatrava (De Oliveira, 1956; Josserand, 2006), or if members joined the Order individually from nearby municipal militias, urban aristocracy (Pizarro, 2006) or even from neighboring kingdoms.

Upon integration with Calatrava, members took monastic vows but some were also knights who held a special social status that dictated the 
kind of foods that they had access to. The consumption of meat such as beef, mutton, goat and sometimes pork was fairly common in the Portuguese medieval diet (Marquez, 1971) but was generally only eaten regularly by elite members of society. Historic documentation from 1189 CE records an observation by a passing crusader that the knights of the Évora Militia ate meat rather frequently compared to lower classes in the middle ages (Lay, 2009). Additionally, as the Order was monastic in nature, the members were expected to abstain from meat on certain holy days throughout the year, including Wednesdays, Fridays and during Lent, amounting to around 150 days per year (Simon, 2009; Alexander et al., 2015). This fasting rule meant that fish was an important supplement to the medieval Christian diet and may have been frequently consumed by members of the Order of Évora (Marques, 1987; Adamson, 2004).

\subsection{Stable isotope use in diet and mobility studies}

Stable isotopes of carbon and nitrogen have become a well-established way to investigate palaeodiet of populations in archaeological science since the 1970s (Vogel and van der Merwe, 1978; DeNiro and Epstein, 1980; Schoeninger and DeNiro, 1983; Sealy and van der Merwe, 1986; Sealy et al., 1987; Schoeninger and Moore, 1992). A number of monastic communities throughout medieval Europe have more recently been included in stable isotope studies to reconstruct diet, and the authors argued that the isotope data was indicative of the aforementioned religious fasting practices, including the increased consumption of fish (Polet and Katzenberg, 2003; Müldner and Richards, 2005; Quintelier et al., 2014; Bownes et al., 2018).

Fractionation of stable carbon isotopes occurs during the photosynthetic processes of plants, which are explained in extensive detail elsewhere (Vogel, 1980; Sealy and van der Merwe, 1986; O'Leary, 1988; Schoeninger and Moore, 1992). The resulting ${ }^{13} \mathrm{C} /{ }^{12} \mathrm{C}$ ratios are characteristic for terrestrial plants that use $\mathrm{C}_{3}, \mathrm{C}_{4}$ or CAM (Crassulacean Acid Metabolism) photosynthetic pathways. $\mathrm{C}_{3}$ plants (including wheat, barley, oats, rice, legumes and all tree species) have $\delta^{13} \mathrm{C}$ values that typically range from $-22 \%$ to $-30 \%$ with an average of around -27\%o (O'Leary, 1988; Malainey, 2010). $\mathrm{C}_{4}$ plants (typically tropical grasses and desert plants adapted for hot, arid environments including millet, sorghum, maize and sugarcane) generally range between $-9 \%$ and $-19 \%$ with an average of around $-13 \%$ (O'Leary, 1988; Malainey, 2010; Loftus and Sealy, 2012; Rao et al., 2012). The consumption of $\mathrm{C}_{3}$ and $\mathrm{C}_{4}$ plants in various proportions influences the ${ }^{13} \mathrm{C} /{ }^{12} \mathrm{C}$ ratios in the bodies of consumers although the extent of fractionation depends on the tissue (bones, teeth etc.) (DeNiro and Epstein, 1978; Schoeninger and Moore, 1992). In animal and human bone collagen, there is an expected trophic level shift of 0-2\%o from prey (food source) to predator (Bocherens and Drucker, 2003). One important consideration is that $\delta^{13} \mathrm{C}$ ratios of bone collagen (expressed as $\delta^{13} \mathrm{C}_{\mathrm{col}}$ ) are mainly derived from the protein component of the diet whereas $\delta^{13} \mathrm{C}$ values from bone apatite or tooth enamel apatite $\left(\delta^{13} \mathrm{C}_{\mathrm{en}}\right)$ are reflective of the whole diet including protein, carbohydrates and lipids (Lee-Thorp et al., 1989; Ambrose and Norr, 1993). Therefore, the use of both $\delta^{13} \mathrm{C}_{\mathrm{col}}$ and $\delta^{13} \mathrm{C}_{\mathrm{en}}$ in isotopic studies can provide a more complete picture of dietary inputs. An important concern, however, is that tooth enamel is formed during childhood, whereas bone collagen is formed throughout life. Thus $\delta^{13} \mathrm{C}_{\mathrm{col}}$ and $\delta^{13} \mathrm{C}_{\mathrm{en}}$ values will reflect the carbon intake from different phases of life in an adult and this must always be taken into account when comparing them.

The nitrogen in bone collagen comes from dietary protein and is significantly ${ }^{15} \mathrm{~N}$-enriched relative to the diet, by approximately $+3-5 \%$ in each successive trophic level (Schoeninger and DeNiro, 1983; Schoeninger et al., 1983; Hedges et al., 2005; Hedges and Reynard, 2007). The comparison of ${ }^{15} \mathrm{~N} /{ }^{14} \mathrm{~N}$ ratios can thus help to reconstruct trophic levels and dietary sources (DeNiro and Epstein, 1980; Malainey, 2010). In infants, elevated $\delta^{15} \mathrm{~N}$ values can also be indicative of breast-feeding, since the child is a trophic level above its mother (Schoeninger and Moore, 1992).

$\delta^{15} \mathrm{~N}$ and $\delta^{13} \mathrm{C}$ can also be indicative of the consumption of large proportions of marine protein, as marine food chains are longer resulting in typically elevated $\delta^{15} \mathrm{~N}$ values in marine organisms and the consumers thereof, as marine organisms are more enriched in ${ }^{13} \mathrm{C}$ than those in terrestrial ecosystems (Mays, 1997). However, as manuring and $\mathrm{C}_{4}$ plant consumption for example, may lead to similar $\delta^{15} \mathrm{~N}$ and $\delta^{13} \mathrm{C}$ enrichment along the foodweb, bone collagen $\delta^{13} \mathrm{C}$ and $\delta^{15} \mathrm{~N}$ can be concomitantly analysed with bone collagen $\delta^{34} \mathrm{~S}$ for identifying the consumption of marine foods by terrestrial animals and humans (Privat et al., 2007; Nehlich et al., 2010).

Moreover, $\delta^{34} \mathrm{~S}$ values may distinguish local and non-local signatures (Nehlich, 2015). Sulphur enters the food web through plants, which in turn get their $\delta^{34} S$ signatures from weathered bedrock, atmospheric deposition (e.g. sea spray) and microbial activity in soil (Krouse, 1989; Hedges et al., 2005). The $\delta^{34} \mathrm{~S}$ values in terrestrial plants vary significantly with location, from $-22 \%$ to $+22 \%$ (Peterson and Fry, 1987; Hedges et al., 2005). Sulphur in collagen, present in the essential amino acid methionine, has negligible isotope fractionation from diet to consumer. Thus $\delta^{34} S$ ratios in animal and human bones originate from those found in the local water sources, soluble soil and bedrock where food was sourced (Richards et al., 2003; Hedges et al., 2005; Nehlich, 2015; Nehlich et al., 2010).

$\delta^{18} \mathrm{O}$ values in skeletal material can also be used as indicators of palaeomobility in archaeological studies. Carbonate oxygen isotopes measured in tooth enamel are good indicators of the isotope values of oxygen found in drinking water and to some extent water from food, as the enamel maintains an isotopic equilibrium with body water as it forms (Sponheimer and Lee-Thorp, 1999; Bowen and Wilkinson, 2002; Darling and Talbot, 2003; Hedges et al., 2004; Pellegrini et al., 2011; Pederzani and Britton, 2019). This ingested water in turn typically reflects the isotopic composition of local meteoric precipitation, which varies geographically and over time (Rozanski et al., 1993; Lightfoot and O'Connell, 2016). Factors such as latitude, altitude, distance to sea, surface air temperature and seasonality can all affect the isotopic composition of precipitation in a certain region (Sharp, 2007; Lightfoot and O'Connell, 2016; Pederzani and Britton, 2019). As a general rule, higher $\delta^{18} \mathrm{O}$ values generally reflect warmer periods, while colder periods may result in lower $\delta^{18} \mathrm{O}$ values but the reality is often more complex (Balasse et al., 2002; Hedges et al., 2005). Therefore, the $\delta^{18} \mathrm{O}$ values in tooth enamel or other skeletal material can be compared to geospatial $\delta^{18} \mathrm{O}$ patterns to reconstruct the life histories of humans and animals in an archaeological context. In order to understand mobility or origins of a population, however, $\delta^{18} \mathrm{O}$ is best used in combination with that of additional geospatially-reactive isotopic systems such as strontium, as oxygen isotopes alone can sometimes show little variation over large geographic areas (Makarewicz and Sealy, 2015; Pederzani and Britton, 2019).

The ${ }^{87} \mathrm{Sr} /{ }^{86} \mathrm{Sr}$ ratios found in an ecosystem generally dependent on the underlying bedrock. Strontium substitutes for calcium during the formation of bioapatite and strontium isotopes do not fractionate from dietary source to consumer or during biomineralisation processes. Therefore, Sr ratios measured in the bioapatite of bones and teeth of animals and humans represent the ratios found in the geological region in which food was sourced during the period of formation of the skeletal tissue (Hedges et al., 2005). In archaeological studies, bioapatite ${ }^{87} \mathrm{Sr} /{ }^{86} \mathrm{Sr}$ ratios have been measured in human skeletons and compared to bioavailable strontium to identify migrant individuals within populations (Montgomery et al., 2003; Price and Gestsdóttir, 2006; Shaw et al., 2016; Diaz-del-Rio et al., 2017).

\subsection{Geological context}

The geological context of Évora is shown in Fig. 2. Évora lies on a contact zone between metamorphic schist and granite that allows for the absorption of moisture, an important feature for agricultural crops 


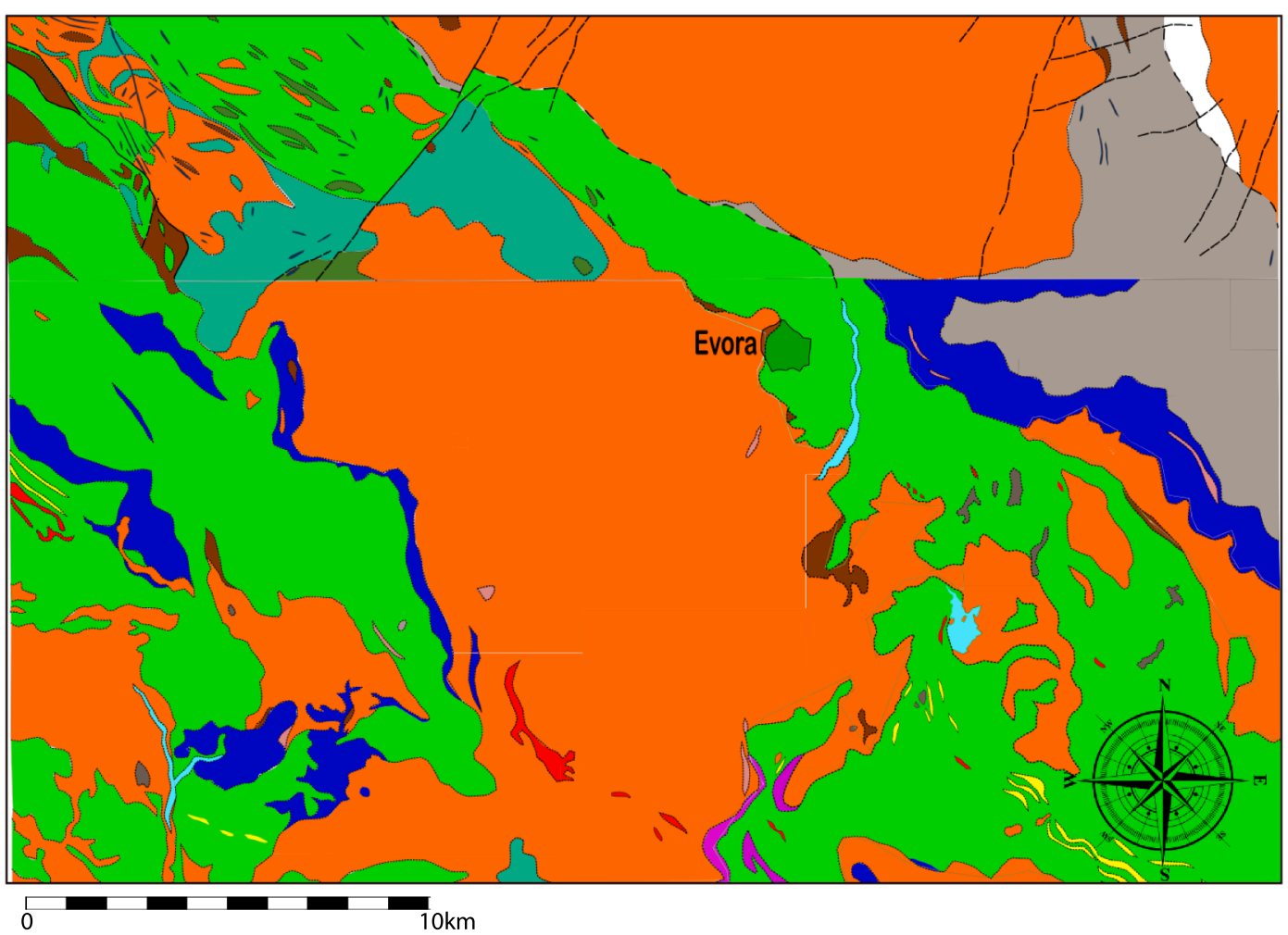

\section{Legend}

\begin{tabular}{|c|c|c|c|}
\hline $\begin{array}{l}\text { Gneiss, } \\
\text { Granitoid \& } \\
\text { Migmatites } \\
\text { (non-porph .) }\end{array}$ & $\begin{array}{l}\text { Porphyroid } \\
\text { Granite, L/M } \\
\text { grained }\end{array}$ & $\begin{array}{l}\text { Cambrian - } \\
\text { Ordovician } \\
\text { inferior }\end{array}$ & $\begin{array}{l}\text { Gravel } \\
\text { Deposits }\end{array}$ \\
\hline $\begin{array}{l}\text { Tonalite , } \\
\text { Quartzodiorite } \\
\text { \& Granodiorite }\end{array}$ & $\begin{array}{l}\text { Gabbro \& } \\
\text { Diorite }\end{array}$ & Quartzites & Pegmatite \\
\hline Micaschistose & $\begin{array}{l}\text { Calcareous } \\
\& \text { Dolomites }\end{array}$ & $\begin{array}{l}\text { Greenstone } \\
\text { (metamorph .+ } \\
\text { chlorite, hornblende } \\
\text { \& epidote) }\end{array}$ & Alluvial \\
\hline Hornfels & $\begin{array}{l}\text { M-grained } \\
\text { Granite, } \\
\text { B iotite }\end{array}$ & $\begin{array}{l}\text { Beja } \\
\text { Porphyry }\end{array}$ & \\
\hline
\end{tabular}

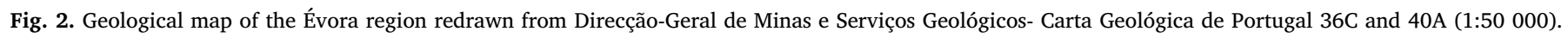

in the spring and early summer (Ribeiro, 1994). The urban centre of the city is located in a morphostructural unit of the Iberian Peninsula called "Maciço Hespérico". The oldest terrain dates from the Upper Proterozoic and in constituted mainly of migmatites and granitoid gneiss. The lithostratigraphic units present are Lower Cambrian (micaschists and amphibole leptynites), Ordovician-Silurian (metavolcanites, amphibolites and micaschists), mid-Devonian and Lower Carboniferous (schists, volcanites and limestones) (Carvalhosa, 1983; Roca and Oliveira, 2005). Radiogenic strontium isotope analysis has been carried out on samples from granitoid outcrops close to Évora (Moita et al., 2009) and other lithotypes from the Évora Massif (Moita et al., 2015) yielding widely varying values, from ${ }^{87} \mathrm{Sr} /{ }^{86} \mathrm{Sr}=0.709$ to ${ }^{87} \mathrm{Sr} /{ }^{86} \mathrm{Sr}=1.1 \mathrm{in}$ Moita et al. (2009) and from ${ }^{87} \mathrm{Sr} /{ }^{86} \mathrm{Sr}=0.704$ to ${ }^{87} \mathrm{Sr} /{ }^{86} \mathrm{Sr}=0.730$ in Moita et al. (2015). These values, however, were based on bulk measurements of the rock and do not reflect the bioavailable strontium values of the region. Minerals within rocks can have highly variable strontium content and isotopic values and as the rock weathers, they will not contribute equally to the bio-available strontium (Price et al., 2002; Bentley, 2006). For this reason, along with varying atmospheric influences, the geological radiogenic strontium values of the regional bedrock is not sufficient for predicting the range of strontium isotope values of organisms living within that region (Makarewicz and Sealy, 2015). To date, no such studies have been conducted for determining the bioavailable strontium isotope values in the vicinity of Évora, but it is hoped that the results obtained through this study will add to the growing corpus of data for Portugal (Waterman et al., 2014; Saragoça et al., 2016; Žalaitè et al., 2018).

\section{Materials}

\subsection{Museu de Évora necropolis}

The Museu de Évora (Fig. 1) underwent remodelling in the 1990s and while expanding the cellars for storage, building foundations from 
Table 1

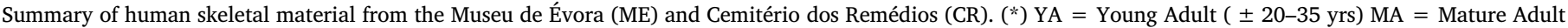
( $\pm 40-60$ yrs) A = Adult (unknown category). $(* *)$ E.477 (fibula) and E.248 (rib) were sampled from the same individual.

Sample Number Human Skeletal Material

Site Sex Est. Age* $\quad$ Burial Type Trauma $\quad$ Knight's Syndrome/ Robust $\quad$ Grave Goods Bone

\begin{tabular}{|c|c|c|c|c|c|c|c|c|c|}
\hline G.251 & ME & M & MA & Christian & $\mathrm{X}$ & $\mathrm{X}$ & Spurs & Fibula (L) & M2 (LR) \\
\hline F. 250 & ME & M & MA & Christian & $\mathrm{X}$ & $\mathrm{X}$ & - & Radius (L) & M1 (LR) \\
\hline C. 249 & ME & M & MA & Christian & & & - & Fibula (R) & M1 (LR) \\
\hline $\begin{array}{l}\text { E. } 248 \\
\text { E. } 477^{* *}\end{array}$ & ME & M & MA & Christian & - & $\mathrm{X}$ & $\begin{array}{l}\text { Buttons } \\
\text { (Calatrava) }\end{array}$ & $\begin{array}{l}\text { Rib (L) } \\
\text { Fibula (R) }\end{array}$ & M2 (LL) \\
\hline ENT-02 & ME & M & YA & Christian & & $\mathrm{X}$ & Metal Buckle & Femur (R) & M1 (UR); M2 (UL); M3 (UR) \\
\hline B.247 & ME & M & YA & Christian & $\mathrm{X}$ & & - & Femur (R) & M1 (LR) \\
\hline J.241 & ME & $\mathrm{U}$ & YA & Christian & & $\mathrm{X}$ & - & Fibula (R) & M1 (UL) \\
\hline G.264 & ME & $\mathrm{U}$ & Infant ( $6 \pm 3$ months) & Christian & & & - & Rib & $\mathrm{n} / \mathrm{a}$ \\
\hline ENT-01 & ME & $\mathrm{F}$ & MA & Islamic & $\mathrm{n} / \mathrm{a}$ & $\mathrm{n} / \mathrm{a}$ & - & Femur (L) & M1 (UL); M2 (UL); M3 (UL) \\
\hline 0.386 & ME & $\mathrm{U}$ & Child (2-4yrs) & Islamic & $\mathrm{n} / \mathrm{a}$ & $\mathrm{n} / \mathrm{a}$ & - & Rib (R) & $\mathrm{n} / \mathrm{a}$ \\
\hline CEIE 101 & CR & M & $\mathrm{U}$ & $\mathrm{n} / \mathrm{a}$ & $\mathrm{n} / \mathrm{a}$ & $\mathrm{n} / \mathrm{a}$ & $\mathrm{n} / \mathrm{a}$ & Femur (L) & $\mathrm{n} / \mathrm{a}$ \\
\hline CEIE 103 & $\mathrm{CR}$ & M & $\mathrm{U}$ & $\mathrm{n} / \mathrm{a}$ & $\mathrm{n} / \mathrm{a}$ & $\mathrm{n} / \mathrm{a}$ & $\mathrm{n} / \mathrm{a}$ & Femur (R) & $\mathrm{n} / \mathrm{a}$ \\
\hline CEIE 96 & CR & $\mathrm{F}$ & $\mathrm{U}$ & $\mathrm{n} / \mathrm{a}$ & $\mathrm{n} / \mathrm{a}$ & $\mathrm{n} / \mathrm{a}$ & $\mathrm{n} / \mathrm{a}$ & Femur $(\mathrm{R})$ & $\mathrm{n} / \mathrm{a}$ \\
\hline CEIE 106 & CR & $\mathrm{F}$ & $\mathrm{U}$ & $\mathrm{n} / \mathrm{a}$ & $\mathrm{n} / \mathrm{a}$ & $\mathrm{n} / \mathrm{a}$ & $\mathrm{n} / \mathrm{a}$ & Femur (L) & $\mathrm{n} / \mathrm{a}$ \\
\hline
\end{tabular}

Roman, Islamic and Medieval Periods were discovered (Santos et al., 1998). Further archaeological investigation revealed housing from at least two phases of occupation during the Islamic caliphate or early taifa period and a Christian necropolis most likely from just after the conquest of Portugal, in addition to Roman and Palaeo-Christian occupation of the site (Gonçalves et al., 1997; Santos and Umbelino, 1997). Excavation of the medieval necropolis in 1996/1997 uncovered nine adult individuals and one infant (in a shared grave with one adult male). They were buried in a typical Christian manner (supine position, E-W orientation) (Santos et al., 1998) above an older level with a tomb housing a child (lateral position, head to SW) and reflecting Islamic religious practice (Torres and Macias, 1995; Santos and Umbelino, 1997). Some of the medieval Christian graves contained metal riding spurs, buckles and buttons bearing the cross of Calatrava from 12th-13th centuries and coins bearing the iconography of the Portuguese Kings Sancho I (1185-1211 CE) and Sancho II (1223-1248 CE) (Gonçalves et al., 1997; Wolfe, 1999). Subsequent excavations in 2007 revealed two more complete burials, a young adult male buried according to Christian practices and an adult female buried in Islamic tradition. (Guerra and Fernandes, 2007). A piece of femur from the adult female was radiocarbon dated to $954 \pm 23$ BP (SUERC-85484) and calibrated using OxCal 4.3.2 (Bronk Ramsey, 2009). Date ranges were calibrated using a mix of the IntCal13 and Marine13 calibration curves (Reimer et al., 2013), giving a date of cal CE 1045-1261 (95.4\% probability; SUERC-85484) and probably cal CE 1060-1242 $(68.2 \%$ probability; SUERC-85484). This age is consistent with the Islamic period prior to, or during, the Christian conquest of Évora in the late 12th century. The location of the Christian burials on an important religious site, that would later be adjacent to the Évora cathedral, could indicate that the individuals held an elite social and/or religious status. As Islamic necropolises are typically located on the urban periphery, the position of this cemetery in the city centre (as illustrated in Fig. 1) is more unusual. Either it was reserved for high-status individuals due to its proximity to the mosque (approximately where the cathedral is now located) (Navarro Palazón and Jiménez Castillo, 2007) or the cemetery was formed out of necessity when it became impossible to reach the necropolis outside the walls and follow customary burial rites while the city was under military siege in 1165 CE (Felipe, 2012; Gonçalves, 2010). This scenario is supported by the radiocarbon dating of the Muslim adult (ENT-01).

\subsection{Anthropological assessment}

Anthropological assessment was carried out by Santos and
Umbelino, 1997, 2007). Six skeletons associated with Medieval Christian burials were classified as male (Table 1), most displayed an overall robustness in their long bones and signs of strong development around areas of muscle attachment that indicate intense and continuous physical activity. Three skeletons displayed characteristics of "Knight's Syndrome" in their femurs and hips, possibly resulting from spending a significant part of their lives on horseback (Farwell and Molleson, 1993; Palfi and Dutour, 1995; Santos and Umbelino, 1997; Guerra and Fernandes, 2007). Furthermore, many of the Christian individuals appear to have traumatic injuries and bone fractures which likely result from interpersonal violence, possibly from blows from heavy weapons such as swords or axes (i.e. upper limb fractures, incisions on skulls and a sternum cracked in half vertically) (Santos and Umbelino, 1997). Injuries of this kind and location imply engagement in violent activity, which for some was the probable cause of death (Santos and Umbelino, 1997; Guerra and Fernandes, 2007). One theory put forward by Mafart et al. (2004) concerning the cut sternum of individual B.247 is that of possible deliberate post-mortem removal of the heart, a known funerary practice among the medieval elite that was observed in the skeleton of an 11th century warrior in France (Mafart et al., 2004). Nevertheless, according to the rules of the Military Order, written in the 17th century, this practice is not mentioned as a funerary ritual. The anthropological indicators of so-called "Knight's Syndrome", general robustness and widespread traumatic injuries consistent with violent attacks together indicate that these individuals had a military role, while the presence of spurs, buckles and buttons with the cross of Calatrava (Gonçalves et al., 1997) support the theory that these Christians were members of the Order of Évora, or the Évora Militia. Furthermore, it could be argued that at least some died in warfare or military campaigns during the 35 or so years that the Order were present to defend the city from Islamic attacks.

\subsection{Selected material}

A list of human skeletal material is given in Table 1 . The bones of ten individuals from the necropolis under the Museu de Évora (hereafter the site is referred to simply as "Museu de Évora") were initially sampled for stable carbon, nitrogen and sulphur isotope analysis. Of these, eight ( $\mathrm{n}=7$ adults; $\mathrm{n}=1$ infant) were from the Christian necropolis and two ( $n=1$ adult; $n=1$ child) appear to be from the Islamic period pre-Christian conquest. Most of the bones sampled were from long bones (femurs, fibulas, tibias and a radius) with the exception of the two children where only ribs were available. Teeth were used from the adults for radiogenic strontium, carbonate stable oxygen and 
Table 2

Summary of faunal material from Convento dos Lóios, Convento dos Remédios and Évora- Rua Diogo Cão.

\begin{tabular}{|c|c|c|c|c|c|}
\hline \multicolumn{6}{|c|}{ Faunal Samples } \\
\hline & $\begin{array}{l}\text { Sample } \\
\text { Number }\end{array}$ & Site & Species & $\begin{array}{l}\text { Common } \\
\text { Name }\end{array}$ & Bone Selected \\
\hline Domestic & L1 & Loios & Sus & Pig & Vertebra \\
\hline Faunal & $\mathrm{L} 2$ & Loios & Sus & Pig & Vertebra \\
\hline \multirow{14}{*}{ Species } & L3 & Loios & Bos taurus & Cow & Vertebra \\
\hline & L4 & Loios & Sus & Pig & Glenoid fossa \\
\hline & L5 & Loios & Bos taurus & Cow & Eye orbit \\
\hline & $\mathrm{R} 1$ & Remédios & Bos taurus & Cow & Vertebra \\
\hline & $\mathrm{R} 2$ & Remédios & Bos taurus & Cow & Vertebra \\
\hline & R4 & Remédios & Sus & Pig & Phalange \\
\hline & R5 & Remédios & $\begin{array}{l}\text { Canis } \\
\text { familiaris }\end{array}$ & Dog & Mandible \\
\hline & R6 & Remédios & Bos taurus & Cow & \multirow[t]{9}{*}{ Calcaneus } \\
\hline & CMRF2 & Évora & Sus & Pig & \\
\hline & CMRF3 & Évora & $\begin{array}{l}\text { Equus } \\
\text { caballus }\end{array}$ & Horse & \\
\hline & CMRF4 & Évora & Bos taurus & Cow & \\
\hline & CMRF5 & Évora & Bos taurus & Cow & \\
\hline & CMRF6 & Évora & $\begin{array}{l}\text { Ovis/ } \\
\text { Capra }\end{array}$ & Sheep/Goat & \\
\hline & CMRF7 & Évora & $\begin{array}{l}\text { Ovis/ } \\
\text { Capra }\end{array}$ & Sheep/Goat & \\
\hline Wild Faunal & R3 & Remédios & Lepus & Hare & \\
\hline Species & CMRF1 & Évora & $\begin{array}{l}\text { Alectoris } \\
\text { rufa }\end{array}$ & $\begin{array}{l}\text { Red-legged } \\
\text { Partridge }\end{array}$ & \\
\hline
\end{tabular}

apatite stable carbon isotopes from enamel. First permanent molars (M1) were selected wherever possible as they indicate the birthplace strontium signature of the individuals. Second molars (M2) were used where M1s were not available, and for two individuals (ENT-01; ENT02) it was possible to sample M1, M2 and M3 teeth to investigate their mobility from early childhood to sub-adult/adulthood. To establish a local signature for radiogenic strontium isotope values, as no data for bioavailable strontium values in the Évora region currently exists, femur bones were used from 4 unidentified adult individuals ( 2 male; 2 female) excavated from Cemitério dos Remédios in Évora dating to the late 19th or early 20th century. These individuals came from a collection composed of a population where the overwhelming majority of those buried in the cemetery had lived and died in Évora, so the likelihood of these four being non-local was very slim. Additionally, as they were buried around a century ago, they are quite unlikely to suffer from severe diagenetic alteration and are expected to retain a good bioavailable strontium signature.

In palaeodietary studies, contemporaneous fauna is typically analysed alongside human bone collagen for estimating habitat-based influence on the geochemical composition of an ecosystem (Bownes et al., 2018). Due to the unique context of the site under study no faunal bones were directly available from the medieval necropolis under the Museu de Évora. Thus, faunal samples (Bos, Equus, Sus, Ovis, Canis lupus familiaris, Lepus, Alectoris rufa) were used from the nearby 17th to 18th century monastery sites of Convento dos Lóios and Convento dos Remédios and 13th to 15th century from Évora- Rua Diogo Cão to establish an environmental baseline for the carbon, nitrogen and sulphur isotopic values. A list of faunal material is given in Table 2.

\section{Methods}

\subsection{Collagen extraction}

A DREMEL ${ }^{\circledR}$ rotary drill with a diamond-coated disc was used to cut approximately 500-700 mg of bone, and each sample was cleaned with a diamond-coated burr to remove excess dirt, discoloration and potential contaminants. Wherever possible, more compact areas were sampled and spongy bone was removed. The Longin (1971) method was used with some slight modification to extract collagen from sampled bone. Each sample was placed in $10 \mathrm{~mL} 0.5 \mathrm{M} \mathrm{HCl}$ for approximately 14 days to demineralize. Samples were vortexed twice daily and spent equal time alternating between room temperature and $4{ }^{\circ} \mathrm{C}$; acid was changed once, after a week. The acid was then removed and samples were rinsed with ultrapure water 5 to 7 times until $\mathrm{pH}$ neutral. Following this, samples were placed in $10 \mathrm{~mL} 0.125 \mathrm{M} \mathrm{NaOH}$ for $20 \mathrm{~h}$ to remove burial contaminants such as humic and fulvic acids (Sealy et al., 2014) and then rinsed 3 to 5 times with ultrapure water until pH neutral. Subsequently, $10 \mathrm{~mL} 0.01 \mathrm{M} \mathrm{HCl}$ was added to each sample, they were placed at $70{ }^{\circ} \mathrm{C}$ for $48 \mathrm{~h}$ to gelatinize and vortexed regularly during this time to break down the pseudomorphs. The remaining liquid was filtered into pre-weighed plastic vials using Ezee-Filter ${ }^{\mathrm{TM}}$ separators (Elkay Laboratory Products) to remove insoluble particles. Collagen was then freeze-dried and vials weighed to obtain collagen yield (see Table 3).

\subsection{Analysis of carbon and nitrogen isotopes}

Around $0.7 \mathrm{mg}$ of the extracted bone collagen was weighed into tin capsules and combusted into $\mathrm{CO}_{2}$ and $\mathrm{N}_{2}$ in an elemental analyser (EA Flash 2000 HT, Thermo Fisher Scientific ${ }^{\circledR}$ ) with oxygen, using pure helium as the carrier gas. The capsules were fed into the EA in a sequence including blank capsules to monitor background and to check for contamination. International reference materials with known stable carbon and nitrogen isotope values, IAEA-CH-6 (sucrose, $\delta^{13} \mathrm{C}=$ $10.499 \%$ ), IAEA-600 (caffeine, $\delta^{13} \mathrm{C}=-27.771 \%$; $\delta^{15} \mathrm{~N}=+1.0 \%$ ) and IAEA-N-2 (ammonium sulphate, $\delta^{15} \mathrm{~N}=+20.3 \%$ ), were used for chemical calibration of proportions between carbon and nitrogen and to determine the composition of the $\mathrm{C}$ and $\mathrm{N}$ isotopes. Capsules with increasing amounts of calibrated in-house standard L-alanine $\left(\delta^{13} \mathrm{C}=-19.17 \% ; \quad \delta^{15} \mathrm{~N}=+4.26 \%\right)$ and aspartic acid $\left(\delta^{13} \mathrm{C}=-36.09 \%\right.$; $\delta^{15} \mathrm{~N}=+10.52 \%$ ) were regularly included in the analytical sequence (every ten analyses) to account and correct for drift and any potential instrumental issues. The isotopic ratios were obtained on a Delta V Advantage Continuous Flow - Isotope Ratio Mass Spectrometer (Thermo Fisher Scientific ${ }^{\circledR}$ ). All sample preparation and analysis of carbon and nitrogen stable isotopes was performed in the HERCULES Laboratory, Universidade de Évora. The isotope values are reported in parts per thousand (\%o) relative to the international standards VPDB (Vienna Pee-Dee Belemnite) for carbon and AIR (Ambient Inhalable Reservoir) for nitrogen. Measurement errors are less than \pm $0.3 \%$ for nitrogen and less than $\pm 0.05 \%$ o for carbon.

\subsection{Stable sulphur isotope analysis}

The sulphur isotope analysis was conducted at SIIAF at the University of Lisbon, using an IsoPrime mass spectrometer. Collagen was combusted with additional $\mathrm{V}_{2} \mathrm{O}_{5}$ and a pulse of oxygen. $\delta^{34} \mathrm{~S}$ was calibrated using the inorganic international standards NBS127 $(+20.3 \%)$, IAEA S1 $(-0.3 \%)$ and casein protein $(+4.0 \%)$ for which the standard deviation was $\pm 0.2 \%$ o $(\mathrm{n}=6)$. Stable sulphur isotope results are reported as $\delta$ values, given in parts per thousand (\%o) relative to VCDT (Vienna-Canyon Diablo Troilite).

\subsection{Stable carbon and oxygen isotopes: Tooth enamel apatite}

The outer surface of the enamel of each tooth was cleaned with a DREMEL $^{\circledast}$ drill to remove soil particles and contaminants. Approximately $15 \mathrm{mg}$ of enamel powder was sampled for stable carbon and oxygen isotope analysis. Following Sponheimer and Lee-Thorp (1999), the powder was placed into $1 \mathrm{~mL} \mathrm{NaOCl}(2-3 \%)$ for $24 \mathrm{~h}$ to remove organic matrix and biogenic contaminants, rinsed four times with ultrapure water and placed into $1 \mathrm{~mL} 1 \mathrm{M}$ acetic acid buffered with Li-acetate solution for $12 \mathrm{~h}$ to remove soluble diagenetic carbonates. 


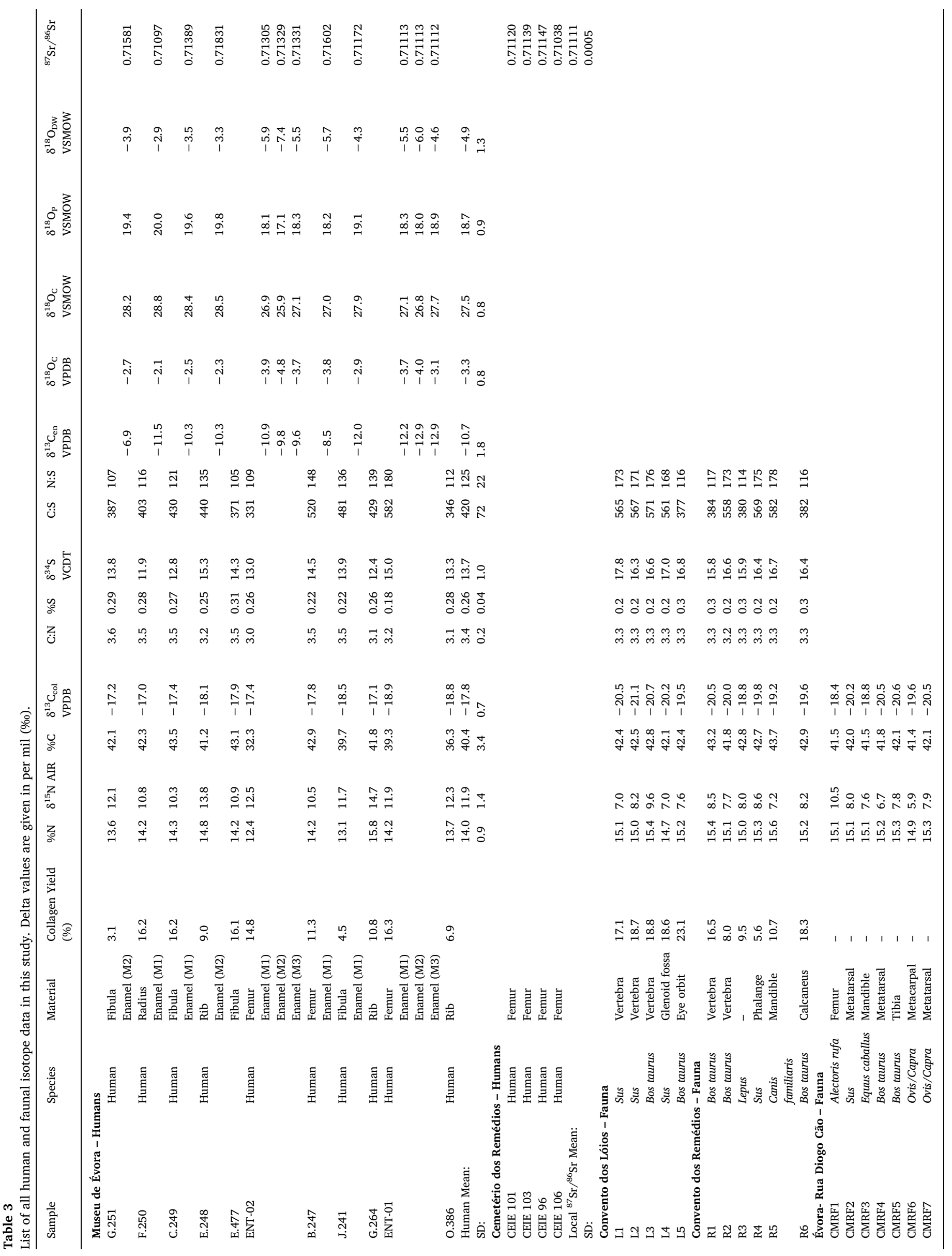


Samples were rinsed again four times with ultrapure water and dried overnight at $70{ }^{\circ} \mathrm{C}$. $800-850 \mu \mathrm{g}$ of enamel powder was then weighed into crucibles and analysed at the Institute of Geosciences, University of Mainz. Samples were dissolved in He-flushed borosilicate exetainers at $72{ }^{\circ} \mathrm{C}$ using a water-free phosphoric acid. The liberated $\mathrm{CO}_{2}$ gas was then measured in a Continuous Flow - Isotope Ratio Mass Spectrometer (Thermo Scientific ${ }^{\circledR} 253$ ) coupled to a GasBench II. Stable isotope ratios were calibrated against a NBS-19 calibrated Carrara Marble $\left(\delta^{13} \mathrm{C}=\right.$ $+2.01 \%$; $\delta^{18} \mathrm{O}=-1.91 \%$ ) distributed by IVA Analysentechnik GmbH \& Co.KG. Results are expressed in parts per thousand (\%o) relative to VPDB. The average precision error $(1 \sigma$; computed from eight injections per sample) was better than $0.06 \%$ for $\delta^{18} \mathrm{O}$ and $0.04 \%$ for $\delta^{13} \mathrm{C}$. The long-term accuracy of the mass spectrometer, based on blindly measured NBS-19 samples ( $\mathrm{N}=421)$, is better than $0.04 \%$ for $\delta^{18} \mathrm{O}$ and $0.03 \%$ for $\delta^{13} \mathrm{C}$.

\subsection{Radiogenic strontium isotopes: Archaeological tooth enamel and recent} bones

Around $35 \mathrm{mg}$ of bone powder was sampled from each of the four human bone samples dated from the 19th/20th century to account for loss of mass during ashing. Samples were placed into pre-weighed clay crucibles and placed in a muffle furnace for $12 \mathrm{~h}$ at $550{ }^{\circ} \mathrm{C}$. Around $20 \mathrm{mg}$ of enamel powder from each tooth from the Museu de Évora adults was sampled for radiogenic strontium isotopes following the same drilling procedure explained above. The ashed bone powder along with the tooth enamel powder then followed the same treatment: around $20 \mathrm{mg}$ of powder was placed into $1.2 \mathrm{~mL}$ acetic acid buffered with Li-acetate for $12 \mathrm{~h}$ then rinsed to neutrality with ultrapure water and dried overnight at $70{ }^{\circ} \mathrm{C}$. Sample digestion and strontium extraction were conducted at the Isotope Geology Laboratory of the University of Aveiro. Sub-boiling distilled nitric acid was used for sample digestion, and $\mathrm{Sr}$ was purified using conventional ion chromatography columns filled with Sr-Resin (Sr-B10-S, 50-100mesh) provided by TrisKem International. The extracted $\mathrm{Sr}$ was loaded onto Ta filaments with $\mathrm{H}_{3} \mathrm{PO}_{4}$ and the isotopic ratios measured with a VG Sector 54 TIMS in dynamic mode with ${ }^{88} \mathrm{Sr}$ peak measurements at 1-2 V. Typical runs consisted of acquisition of 60 isotopic ratios and the analytical data were corrected for mass fractionation relative to ${ }^{88} \mathrm{Sr} /{ }^{86} \mathrm{Sr}=0.1194$. The standard reference material NIST SRM 987 was concomitantly measured and provided a value of ${ }^{87} \mathrm{Sr} /{ }^{86} \mathrm{Sr}=0.710266 \pm 0.000016$ (conf. limit 95\%, $\mathrm{N}=13$ ). The procedure average blanks levels were less than $1 \mathrm{ng}$, which are negligible compared to the total amount of $\mathrm{Sr}$ processed in the analytical protocol.

\section{Results}

\subsection{Carbon and nitrogen isotopes}

\subsubsection{Bone collagen}

Isotope results are provided in Table 3 . All human bone collagen samples meet the established quality criteria for stable carbon and nitrogen isotope analyses (Ambrose, 1990; DeNiro, 1985). The atomic C:N ratios as well as the carbon and nitrogen amounts (\%) fell within the acceptable ranges for good preservation. The faunal collagen samples were also well preserved and met the above-mentioned criteria. The analysis of stable carbon and nitrogen isotopes of the human bone collagen resulted in a mean $\delta^{13} \mathrm{C}_{\text {col }}$ value of $-17.8 \pm 0.7 \%$ (ranging from -18.9 to $-17.0 \%$ ) and a mean $\delta^{15} \mathrm{~N}$ value of $11.9 \pm 1.4 \%$ (ranging from 10.3 to $14.7 \%$ ). The $\delta^{13} \mathrm{C}_{\mathrm{col}}$ and $\delta^{15} \mathrm{~N}$ values for the fauna range from -21.1 to $-18.4 \%$ and 5.9 to $10.5 \%$, respectively.

It is important to consider isotope values of human skeletal material (bones, teeth) in relation to local faunal values rather than in isolation, to account for any regional variation that can result in ambiguous isotope values as occurred in Tauste (Guede et al., 2017a) and Yorkshire (Bownes et al., 2018). Although the faunal samples belong to more recent periods (Lóios and Remédios: 17th-18th centuries; ÉvoraRua Diogo Cão: 13th-15th centuries) than the human skeletons from Museu de Évora (12th-13th centuries), they yield very similar $\delta^{13} \mathrm{C}$ and $\delta^{15} \mathrm{~N}$ data. The $\delta^{13} \mathrm{C}$ and $\delta^{15} \mathrm{~N}$ averages overlap for the cows from Lóios and Remédios respectively, and while one cow from Rua Diogo Cão has lower $\delta^{15} \mathrm{~N}$, the difference of values within Lóios was greater than the total difference between all three sites. As for pigs, the three from Lóios cannot be numerically compared to the one from Rua Diogo Cão. As we have few samples from each site, all within $1 \mathrm{~km}$ of each other, it is more prudent to consider the samples together and have a more representative faunal data set. The $\delta^{13} \mathrm{C}_{\mathrm{col}}$ values of the fauna are indicative of $\mathrm{C}_{3}$ plant consumption, but when a trophic level shift of 0-2\%o (Lee-Thorp et al., 1989; DeNiro and Epstein, 1978) is applied to the faunal mean values (for cows and pigs), only three human individuals fall within the expected range (see Fig. 3). These individuals are the Muslim adult and child (ENT-01 and 0.386, respectively) and the young Christian adult J.241. Regarding the $\delta^{15} \mathrm{~N}$ values, most of the individuals fall within the expected trophic level increase of $3-5 \%$ (Hedges and Reynard, 2007) above the faunal mean values with two exceptions from the Christian population. G.264, an infant (3-9 months) has a higher $\delta^{15} \mathrm{~N}$ value of $14.7 \%$, which is most likely a breastfeeding signal (Fogel et al., 1989). An adult male (E.248), has a high $\delta^{15} \mathrm{~N}$ value (13.8\%) in the rib but not a very high $\delta^{13} \mathrm{C}_{\text {col }}$ value, which means that marine fish protein input is unlikely but could result from the consumption of freshwater fish (Knipper et al., 2015). For this same individual, stable carbon and nitrogen values were also measured in the fibula (E.477) and while $\delta^{13} \mathrm{C}_{\text {col }}$ values were similar, there was a difference of nearly $3 \%$ in the $\delta^{15} \mathrm{~N}$ values (10.9\%), indicating a probable change in diet, although we cannot know the length of time that diet has been recorded in the respective bones. Bone turnover rates are still widely discussed with huge variation estimated, depending on the bone type, age of individual and gender among other factors (Hedges et al., 2007; Fahy et al., 2017). For this reason, the association of stable isotope ratio values in particular bone types with behaviour in particular periods of life must be done with caution.

\subsubsection{Enamel apatite}

Stable carbon isotope values were obtained from tooth enamel of eight individuals (Table 3) resulting in a mean $\delta^{13} \mathrm{C}_{\text {en }}$ value of $-10.7 \pm 1.8 \%$ (ranging from -12.9 to $-6.9 \%$ ). According to LeeThorp (2008) there is an expected diet to bone carbonate $\delta^{13} \mathrm{C}$ offset of around $+12 \%$, while Passey et al. (2005) found a diet to tooth enamel offset that varied between +11 and $+13.5 \%$ in a controlled diet study on animals. In a scenario where human diets were based entirely on $\mathrm{C}_{3}$ foods, one could anticipate $\delta^{13} \mathrm{C}$ bone apatite or enamel values of around $-14 \%$ whereas a purely $\mathrm{C}_{4}$ diet would yield values close to ca. 0\%o (Diaz-del-Rio et al., 2017). Conversely, values that fall in between this range, as is the case for the Museu de Évora skeletons, suggest mixed dietary inputs at the time of enamel formation. The combination of stable carbon isotopes obtained from bone collagen $\left(\delta^{13} \mathrm{C}_{\mathrm{col}}\right)$ and enamel apatite $\left(\delta^{13} \mathrm{C}_{\mathrm{en}}\right)$ of the same individuals provides a clearer picture of the carbon contribution from protein and whole diet (carbohydrates and lipids) respectively. To understand this better, the $\delta^{13} \mathrm{C}$ values for these skeletons were plotted against the regression lines developed by Kellner and Schoeninger (2007) in Fig. 4. These regression lines were formulated from a number of controlled feeding experiments and indicate expected values for main protein sources $\left(\mathrm{C}_{3}, \mathrm{C}_{4}\right.$ or marine) while vertical position on the lines indicate energy source $\left(\mathrm{C}_{3}, \mathrm{C}_{4}\right.$ or mixed). From this, we can see that the protein in the diet of this population was predominantly $\mathrm{C}_{3}$-based although F.250 had a 


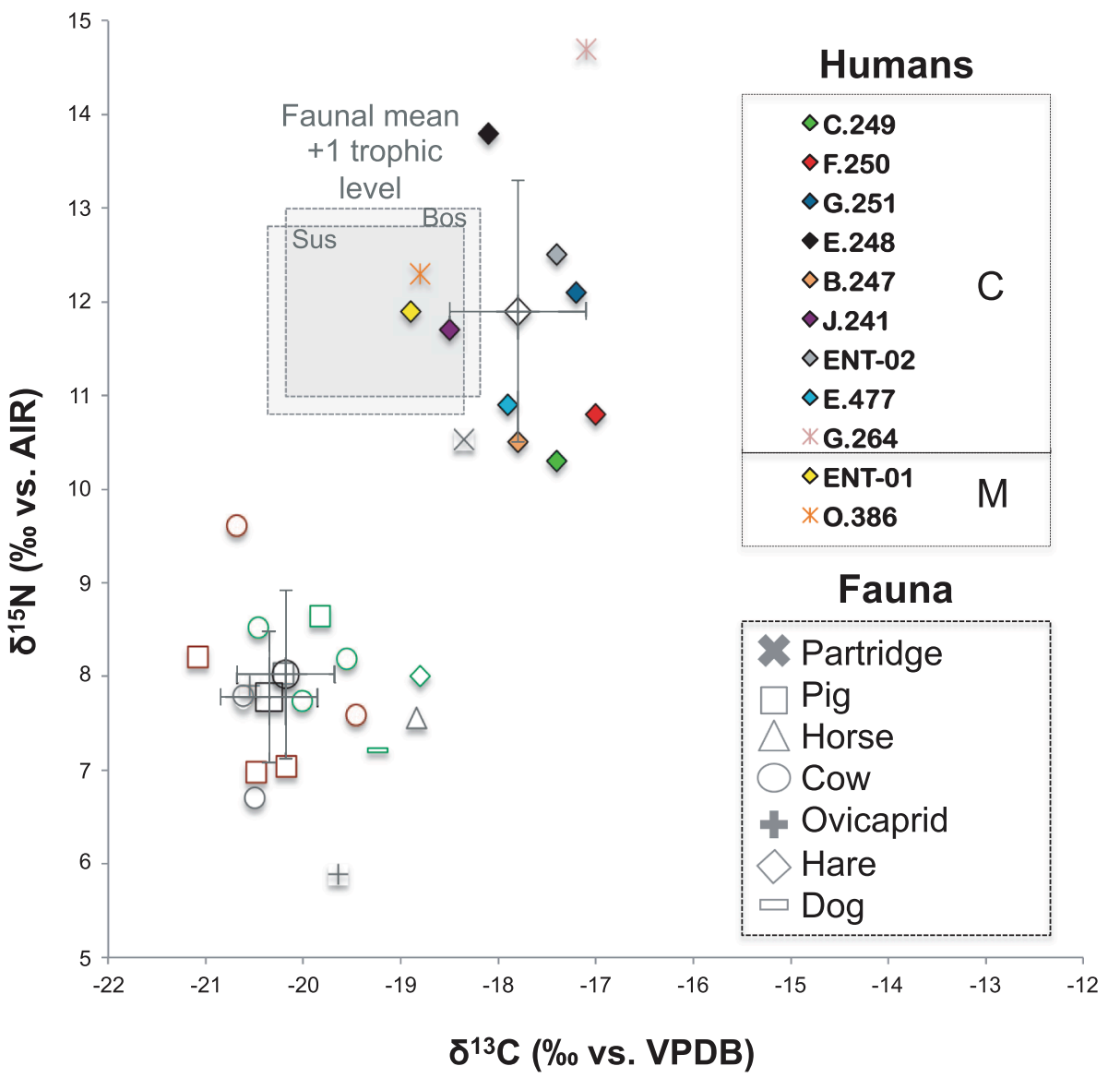

Fig. 3. $\delta^{13} \mathrm{C}$ and $\delta^{15} \mathrm{~N}$ values for Museu de Évora humans (Christian and Muslim) and fauna from Convento dos Lóios (red), Convento dos Remédios (green) and Évora- Rua Diogo Cão (grey). Expected +1 trophic level shift range is given for Bos and Sus mean values.

higher $\delta^{13} \mathrm{C}_{\text {col }}$ value and may have had more marine or $\mathrm{C}_{4}$ protein input. Regarding energy source, there appears to be some mixing of $\mathrm{C}_{3}$ and $\mathrm{C}_{4}$ resources to varying degrees. Once again, the Muslim adult (ENT-01) and Christian adult (J.241) have similar bone and enamel stable carbon isotope values that indicates mostly $\mathrm{C}_{3}$ protein and energy sources while the rest of the Christian adults have more diverse enamel values, as is the case for their $\delta^{13} \mathrm{C}_{\mathrm{col}}$. It is important to consider, however, that bones and teeth are formed during different periods of life and therefore $\delta^{13} \mathrm{C}_{\mathrm{col}}$ and $\delta^{13} \mathrm{C}_{\mathrm{en}}$ are not temporally equivalent in this case.

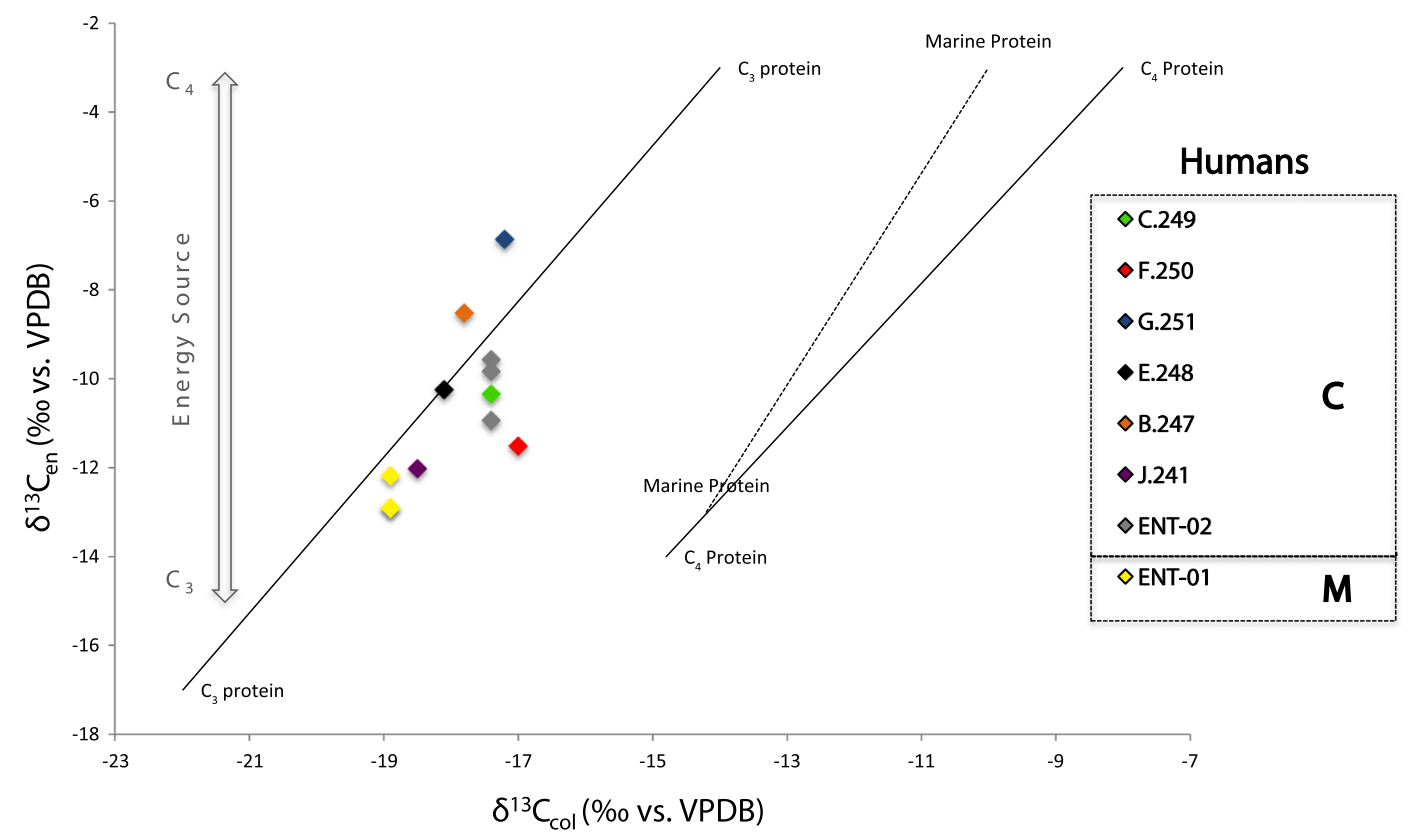

Fig. 4. Museu de Évora $\delta^{13} \mathrm{C}_{\mathrm{col}}$ and $\delta^{13} \mathrm{C}_{\mathrm{en}}$ values plotted against regression lines developed by Kellner and Schoeninger (Kellner and Schoeninger, 2007) indicating main protein and energy sources of diet. 


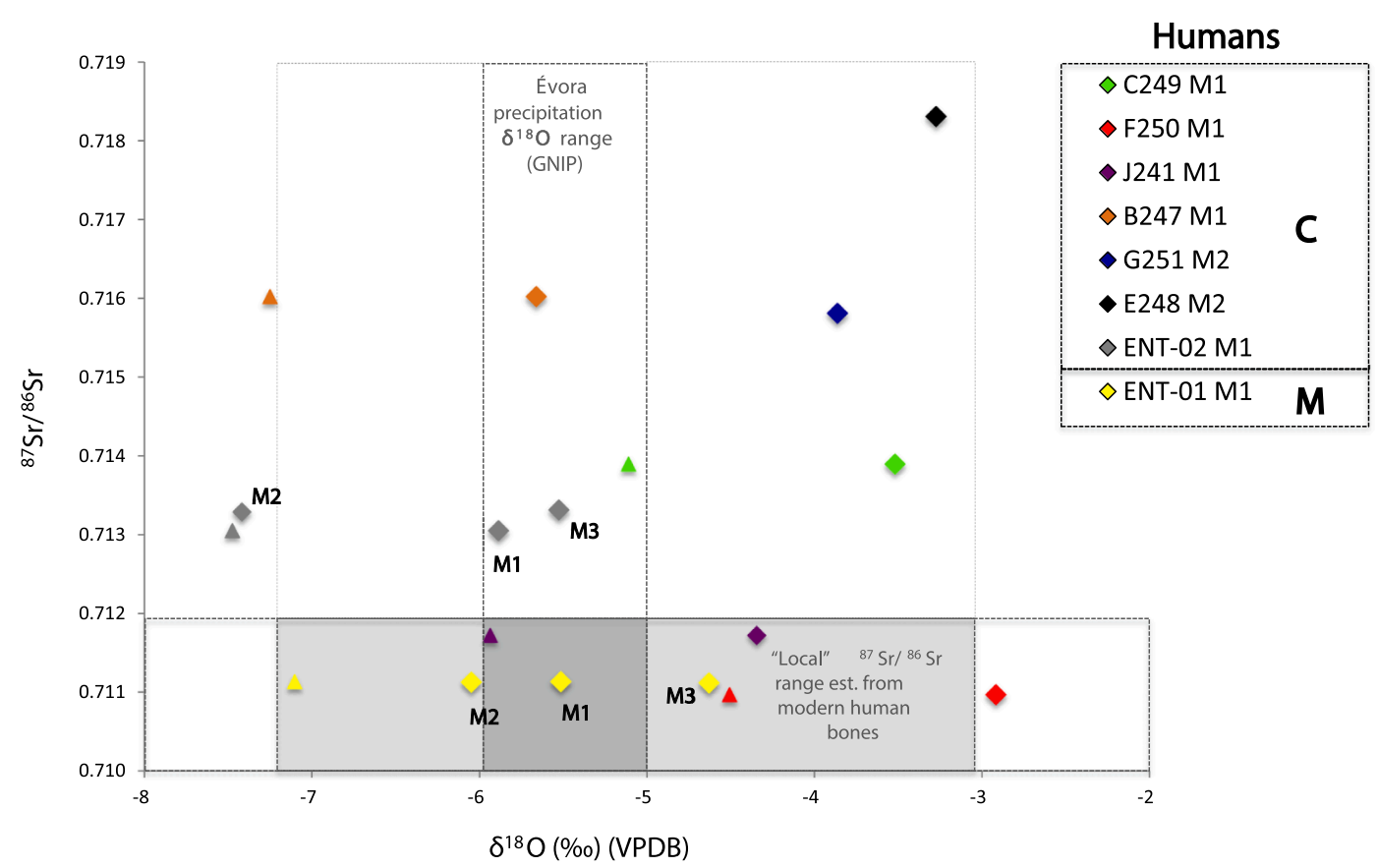

Fig. $5 .{ }^{87} \mathrm{Sr} /{ }^{86} \mathrm{Sr}$ and $\delta^{18} \mathrm{O}$ isotope values for Museu de Évora skeletons. For individuals where multiple teeth were samples, tooth type is labeled. Triangles correspond to estimated $\delta^{18} \mathrm{O}$ values of $\mathrm{M} 1$ corrected for breastfeeding effect $\left(-1 \%\right.$, cf. 4.2). Expected "local" ranges for Évora estimated from averaged ${ }^{87} \mathrm{Sr} /{ }^{86} \mathrm{Sr}$ values obtained from Cemitério dos Remédios human bones and GNIP precipitation data $\left(\delta^{18} \mathrm{O}\right)$ - recorded annual averages are shaded in darker grey and seasonal variability in lighter grey.

\subsection{Oxygen and strontium isotopes}

The $\delta^{18} \mathrm{O}$ values were converted from VPDB to VSMOW (Vienna Standard Mean Ocean Water) values using the equation published by Coplen (1988). The $\delta^{18} \mathrm{O}$ values were converted from carbonate $\left(\delta^{18} \mathrm{O}_{\mathrm{C}}\right)$ to phosphate $\left(\delta^{18} \mathrm{O}_{\mathrm{P}}\right)$ values because although $\delta^{18} \mathrm{O}_{\mathrm{C}}$ is quicker, easier and less expensive to measure, carbonate ions are thought to be more susceptible to diagenetic alteration, and the relationship between $\delta^{18} \mathrm{O}_{\mathrm{P}}$ values in bioapatite and drinking water $\left(\delta^{18} \mathrm{O}_{\mathrm{DW}}\right)$ is better understood (Daux et al., 2008; Chenery et al., 2012). This conversion was done using the equation published by Chenery et al. (2012), which was based on a regression line, developed by these authors, that compared well to $\delta^{18} \mathrm{O}_{\mathrm{C}}$ and $\delta^{18} \mathrm{O}_{\mathrm{P}}$ bioapatite studies of other bone remains (Iacumin et al., 1996; Tütken et al., 2008; Metcalfe et al., 2009). In order to compare the bioapatite oxygen values to meteoric water, they first need to be converted to drinking water $\left(\delta^{18} \mathrm{O}_{\mathrm{DW}}\right)$ values. There are uncertainties involved in making such conversions, as discussed by Pollard et al. (2012), Pryor et al. (2014), Lightfoot and O'Connell (2016) and others. Pollard et al. (2012) along with Leach et al. (2009) attempted to avoid these issues by creating an estimated range of $\delta^{18} \mathrm{O}_{\mathrm{P}}$ values for UK populations. While this works well enough in the UK where there is an abundance of oxygen isotope data, the same cannot be said for Portugal currently, so we must cautiously rely on such equations. Following Chenery et al. (2012), the $\delta^{18} \mathrm{O}_{\mathrm{C}}$ values were converted directly into $\delta^{18} \mathrm{O}_{\mathrm{DW}}$ values using the Equation (6) published by Daux et al. (2008) $\left(\delta^{18} \mathrm{O}_{\mathrm{DW}}=1.590 \times \delta^{18} \mathrm{O}_{\mathrm{C}}-48.634\right)$. Equation (4) (Daux et al., 2008) was also calculated for comparison, but the results yielded were either the same or $0.1-0.2 \%$ different, so the results from the former equation are thus reported. These values are provided in Table 3.

To establish precipitation $\delta^{18} \mathrm{O}$ values for the city of Évora, Global Network of Isotopes in Precipitation (GNIP) data was obtained from IAEA (WISER - Water Isotope System for data analysis, visualization and Electronic Retrieval, 2018). The annual $\delta^{18} \mathrm{O}$ averages ranged from -5.08 to $-5.9 \%$ for $2014-2017$ but since data was only available for a short period of time, and oxygen isotope data in precipitation is thought to fluctuate short-term (between seasons, years and/or decades) (Rozanski et al., 1993; Lightfoot and O'Connell, 2016), a more conservative range would probably be representative of local water precipitation values for Évora. Indeed the GNIP averages for the summertime months of June and September have been recorded as high as $-3.1 \%$ and $-3.25 \%$ respectively and as low as $-7.3 \%$ in March for 2014-2017, so this range should account for long term fluctuation over time in Évora. Therefore, Fig. 5 indicates the range of measured precipitation $\delta^{18} \mathrm{O}$ values (shaded in dark grey) along with the potential seasonal fluctuation (shaded in light grey) based on the available data. The Muslim adult (ENT-01) as well as three Christian young adults (J.241, B.247, ENT-02) all have $\delta^{18} \mathrm{O}_{\mathrm{DW}}$ values that fall within the proposed local range (see Fig. 5) while the individuals F.250, C.249, E.248 and G.251 have higher $\delta^{18} \mathrm{O}_{\mathrm{DW}}$ values, which are consistent with an origin in a warmer, more coastal or more arid environment.

For most of the individuals, M1s were selected to represent the birthplace signature for strontium analysis, but this complicates matters for oxygen isotope values and is not ideal (Evans et al., 2012). The enamel that forms during breastfeeding can be enriched due to isotopic fractionation in the body water of the mother, resulting in $\delta^{18} \mathrm{O}$ values that are between 0.5 and $1.2 \%$ higher than the enamel which forms later (Wright and Schwarcz, 1998; Pederzani and Britton, 2019). When a correction of $-1 \%$ was applied to the $\delta^{18} \mathrm{O}_{\mathrm{C}}$ values for all M1s and they were recalculated, the $\delta^{18} \mathrm{O}_{\mathrm{DW}}$ values were as follows: C.249: $-5.1 \%$; F.250: $-4.5 \%$; J.241: - 5.9\%; B.247: -7.3\%o; ENT-02: $-7.5 \%$ and ENT:01: $-7.1 \%$. These "corrected" values are represented by the triangles in Fig. 5. For the individuals C.249 and F.250, this would place them within the proposed local range of precipitation $\delta^{18} \mathrm{O}$ values for Évora, while B.247, ENT-02 and ENT-01 would have $\delta^{18} \mathrm{O}_{\mathrm{DW}}$ values lower than the local range in their M1s. It is, however, impossible to know the extent at which a breastfeeding signal is recorded in the teeth. There is great variability in how and where enamel forms, and at what rate (Balasse, 2002; Reid and Dean, 2006; Humphrey et al., 2008) so the offset will not be uniform within a tooth. Even when great care is taken to sample from enamel, it is still difficult to interpret the potential influence of a breastfeeding signal. Nevertheless, in Portugal, $\delta^{18} \mathrm{O}$ precipitation values are not highly variable due to its small size, which limits discussions of provenance, so the addition of ${ }^{87} \mathrm{Sr} /{ }^{86} \mathrm{Sr}$ values can provide some clarity. 
In order to determine the local bioavailable radiogenic strontium isotope baseline, human bones from four adult individuals buried in the last century at Cemitério dos Remédios were analysed on the premise that their bones may yield a local signal. They provided ${ }^{87} \mathrm{Sr} /{ }^{86} \mathrm{Sr}$ values ranging between 0.71038 and 0.71147 , and the consistency of the values between the four supports the idea that they were local. The mean $\pm 2 \sigma$ of the ${ }^{87} \mathrm{Sr} /{ }^{86} \mathrm{Sr}$ values of these bones was used to establish a range of 0.710 to 0.712 for the local bioavailable strontium signal, following Scheeres et al. (2014). Once again, the Muslim adult (ENT01) fell within this range for all teeth sampled (M1, M2, M3) $\left({ }^{87} \mathrm{Sr} /{ }^{86} \mathrm{Sr}=0.711\right)$, as did young adult $\mathrm{J} .241\left({ }^{87} \mathrm{Sr} /{ }^{86} \mathrm{Sr}=0.712\right)$ and mature adult F.250 $\left({ }^{87} \mathrm{Sr} /{ }^{86} \mathrm{Sr}=0.711\right)$, both Christian. All other Christian adults, however, displayed a wide range of ${ }^{87} \mathrm{Sr} /{ }^{86} \mathrm{Sr}$ values (see Table 3) ranging from 0.713 to 0.718 . Higher radiogenic strontium isotope values correspond with origins in regions with older geological formations than Évora.

\subsection{Sulphur isotopes}

Both the human and faunal bone collagen met the quality criteria established by Nehlich and Richards (2009) and the atomic C:S and N:S ratios and sulphur amounts (\%) indicated good preservation (see Table 3). Human bone collagen yielded a mean $\delta^{34} S$ value of $13.7 \pm 1.0 \%$ (ranging from 11.9 to $15.3 \%$ ) while the $\delta^{34}$ S values of the Remedios and Lóios fauna ranged from 15.8 to $17.8 \%$. Collagen to diet offset for stable sulphur isotope values is thought to be quite negligible (Nehlich, 2015; Richards et al., 2003), but the faunal $\delta^{34} \mathrm{~S}$ values are noticeably higher than the human values (see Table 3), particularly the Christians. This may be explained by the consumption of a protein source with lower $\delta^{34} S$ values, for example, if the individuals were consuming freshwater fish that had $\delta^{34} \mathrm{~S}$ values lower than the local terrestrial fauna. Sulphur isotopes in freshwater environments have been found to be highly variable, ranging from -22 to $+20 \%$ (Privat et al., 2007) and considering how enriched in sulphur the terrestrial fauna is in this study, it is possible that the addition of ${ }^{34} \mathrm{~S}$-depleted freshwater fish to human diets would result in lower human $\delta^{34} \mathrm{~S}$ values. Terrestrial organisms typically have $\delta^{34} \mathrm{~S}$ values ranging between -5 and $+10 \%$ but may be substantially enriched in geological settings containing evaporitic rocks (Privat et al., 2007) and in coastal zones by a "sea-spray" effect (Nehlich et al., 2012; Nehlich, 2015; Krouse, 1989) whereby the terrestrial ecosystem incorporates large quantities of evaporated marine sulphates carried by sea breeze. As illustrated in Fig. 2, and explained in section 1.3, Évora is located in a region dominated by igneous and metamorphic bedrock but there are a few small calcareous zones within $10 \mathrm{~km}$ of the city, which could plausibly be grazing areas for domestic fauna. Although Évora is inland, recent studies have monitored the movement of Saharan dust particles across the southern Iberian Peninsula, which bring with them evaporated sea-spray from the Mediterranean (Conceicao et al., 2018; Rodriguez-Navarro et al., 2018). A study dedicated to the chemical characterisation of aerosol particles in the city of Évora observed an increase in sulphates and sea-salts during summer that coincides with the trajectories of Saharan dust across Iberia (Tobias, 2013). This could explain the high faunal $\delta^{34} S$ values if the airborne marine sulphates significantly enrich the terrestrial ecosystem, but until further research into sulphur isotopes is conducted in the southern Iberian Peninsula, it is difficult to know the extent of this influence.

\section{Discussion}

\subsection{Origins and identity}

The stable oxygen isotope data is difficult to interpret in the context of mobility, particularly considering the potential offset in M1s that could be obscuring the "true" value produced from regional meteoric oxygen levels. In fact in Iberia overall, regional variability in precipitation $\delta^{18} \mathrm{O}$ values is quite low and difficult to distinguish. To illustrate an example, in Ciudad Real, around $12 \mathrm{~km}$ from Calatrava La Vieja- the site originally occupied by the Order of Calatrava and a possible homeland of some members of the Évora Militia- GNIP precipitation data records annual averages ranging from $-8.6 \%$ to $-5.2 \%$ with a median of $-6.3 \%$ (WISER- Water Isotope System for data analysis, visualization and Electronic Retrieval IAEA, 2018) This overlaps a lot with the recorded annual averages for Évora $(-5.9 \%$ to $-5.1 \% 0$ ), making it difficult to distinguish, based on oxygen alone, if indeed some of the individuals (such as B.247 and ENT.02) did come from Calatrava. While many of the Christian adults had $\delta^{18} \mathrm{O}_{\mathrm{DW}}$ higher than the ranges of both Ciudad Real and Évora, the same issue of limited variability makes it difficult to suggest specific regions of origin. The lack of available data is another issue, but it is hoped that $\delta^{18} \mathrm{O}$ values obtained through studies such as this in Iberia can contribute to a growing database so that in the future researchers may rely less on precipitation data.

When the $\delta^{18} \mathrm{O}$ and ${ }^{87} \mathrm{Sr} /{ }^{86} \mathrm{Sr}$ values are considered together in the context of expected ranges for Évora, as illustrated in Fig. 5, a clearer picture emerges. The Muslim adult's (ENT-01) isotope values for radiogenic strontium as well as oxygen, carbon and nitrogen consistently fall within the expected local range, indicating that she was a local, as anticipated. More surprising is the case of Christian adult J.241 who had very similar isotope signatures to ENT-01 for all proxies except sulphur, which was slightly lower. The range of ${ }^{87} \mathrm{Sr} /{ }^{86} \mathrm{Sr}$ values for the other adult Christians (0.713-0.718) indicates not only that these individuals were non-local, as most of their values were more radiogenic than the established bioavailable range $(0.710-0.712)$, but also that they were most likely from different places. It is unlikely that such diversity could occur within a single geographic region, and for this reason it is difficult to compare the ${ }^{87} \mathrm{Sr} /{ }^{86} \mathrm{Sr}$ values of the Christian individuals to the bioavailable strontium of any specific place, since they do not appear to form subgroups of similar values. It is possible that at least some of these Christians came from Calatrava, something that could be hypothesised with more confidence by obtaining the bioavailable ${ }^{87} \mathrm{Sr} /{ }^{86} \mathrm{Sr}$ signature of that region. The need for a broader dataset of bioavailable ${ }^{87} \mathrm{Sr} /{ }^{86} \mathrm{Sr}$ values within Portugal specifically, and across Iberia generally, is also clear here as deeper insight into possible provenance is not currently possible. We can hypothesise that while most Order members arrived in Évora from elsewhere during the conquest, some may have joined locally, perhaps from urban aristocracy or even as converts from the Islamic population. This is possible considering that J.241 appears to have been born locally, according to the ${ }^{87} \mathrm{Sr} /{ }^{86} \mathrm{Sr}$ and $\delta^{18} \mathrm{O}_{\mathrm{DW}}$ values, and died quite young, presumably during the conquest effort or shortly thereafter. This hypothesis, however, warrants further historical investigation. Mobility and diverse geographic recruitment of members are two apparent trends of the composition of this militia.

Taking into account the times of different molar formation, the consistency of ${ }^{87} \mathrm{Sr} /{ }^{86} \mathrm{Sr}$ values where multiple teeth were analysed per individual (ENT-01 and ENT-02) indicates that these individuals were not mobile between infancy and young adulthood. For ENT-02 $\left({ }^{87} \mathrm{Sr} /{ }^{86} \mathrm{Sr}=0.713\right)$, a Christian male aged around $30-34$ years, the consistency of ${ }^{87} \mathrm{Sr} /{ }^{86} \mathrm{Sr}$ values in all three molars provides evidence of the arrival of Order members as adults to Évora as the tooth crowns were formed between birth and \pm 12 years (Smith, 1991). This is further supported by the age at death of the Christians (many appear to be in their late 50 s, although methods for age estimation are not completely reliable) (Santos and Umbelino, 1997) and considering that the Order of Évora was mainly present in the city between 1176 and $1211 \mathrm{CE}$ it is probable that most members were already adults when they arrived.

In addition to geographic diversity of origins demonstrated by the ${ }^{87} \mathrm{Sr} /{ }^{86} \mathrm{Sr}$ values of the Christian adults, $\delta^{13} \mathrm{C}_{\mathrm{en}}$ values may provide some evidence of social diversity. The enamel formed early in life possibly reflects a higher input of $\mathrm{C}_{4}$ plant sources during childhood than might 
be expected for these supposedly high-status individuals as adults (see Fig. 4). Choice of grain was often determined by social status in Medieval Europe, so $\mathrm{C}_{4}$ plants like millet were consumed by the poor or used as animal feed while the elites ate more $\mathrm{C}_{3}$ cereals like wheat and barley (Adamson, 2004). While the Order members may have held high social status when they died (and in the years immediately prior) and eaten accordingly, it is possible that some had more humble social origins earlier in life, which could explain the diversity in $\delta^{13} \mathrm{C}_{\mathrm{en}}$ values, a result of grain choice or availability.

\subsection{Diet and social status}

It is necessary to consider that because of bone turnover rates, the bone collagen represents diet averaged over the last years of the lives of these individuals. While we know that the Order of Évora was mainly present in the city from 1176 to $1211 \mathrm{CE}$, we cannot know how soon these individuals died after their arrival, and thus to what extent their bone collagen reflects their diet pre- or post-arrival. The Muslim chronicler Ibn Idhāri recorded an episode in $1181 \mathrm{CE}$ whereby the Sevillian commander Ibn Wānūdīn besieged Évora for some days (Beirante, 1995). The Évora Militia attacked the Muslim camp in retaliation but many of the Christian raiders were captured or killed in the process. If some, or all, of the Christian individuals died in this event, they may have only been living in the city for five or so years prior to death, and therefore their bone collagen could represent their pre-arrival diet. In this case, we could expect great inter-individual diversity in the $\delta^{13} \mathrm{C}_{\mathrm{col}}$ and $\delta^{15} \mathrm{~N}$ values consistent with their diverse geographical and perhaps social origins. On the other hand, the presence of coins in the Christian necropolis, bearing the iconography of D. Sancho I (r.1185-1211) and D. Sancho II (r.1223-1248) (Gonçalves et al., 1997) may place the deaths of at least some of the individuals at a slightly later date, meaning that their bone collagen could reflect more of their post-arrival diet. This greatly complicates the interpretation of stable carbon and nitrogen values from bone collagen in the context of locally obtained fauna, since we cannot say for certain how much of their post-arrival diet is reflected in the bones. Perhaps the most compelling evidence for a change in diet comes from the isotope values of the adult Christian of which both a rib (E.248) and a fibula (E.477) were analysed. The radiogenic strontium measured in the M2 of this individual is the highest in this group (0.718), indicating a non-local origin, and the presence of a button bearing the cross of Calatrava in the grave could be evidence that he himself came from Calatrava. While we cannot know for sure the difference in turnover rates between the rib and fibula, a $3 \%$ difference in the $\delta^{15} \mathrm{~N}$ values for the two bones of this individual imply a change in dietary protein intake in the years prior to the individual's death. This individual's $\delta^{34} \mathrm{~S}$ value $(15.3 \%$ ) from the rib (E.248) was also the closest to the faunal sulphur values, although still ultimately lower, which could be suggestive of more local terrestrial dietary inputs than the majority of the Christians in the last years of life. In the case of Richard III, Lamb et al. (2014) also observed a large increase (1.4\%o) in $\delta^{15} \mathrm{~N}$ values between the femur and rib of his skeleton, which they associated with a change in diet coinciding with a shift in social status when he became the King of England at the age of 30. It should be noted, however, that the length of time recorded in different types of bone is still under debate (Fahy et al., 2017). For the Christian adult (E.248/E477) this increase in $\delta^{15} \mathrm{~N}$ values would be consistent with moving to Évora in adulthood and taking up different dietary practices. If the Order members were living in Évora for long enough for their bone collagen to adjust to post-arrival dietary habits, then their isotope values could reflect religious fasting behaviour.

Rather than considering this population in isolation, we can contextualise the dietary data with other studies on Medieval Christian and Muslim populations from Portugal and Spain, to see if there is an observable pattern. Thirty sites from the Iberian Peninsula as well as five studies from monastic or other religious populations in Britain, Belgium and France (Polet and Katzenberg, 2003; Müldner and Richards, 2005;
Quintelier et al., 2014; Colleter et al., 2017; Bownes et al., 2018) were compared to the Museu de Évora population average. Data from domestic herbivores only was used for this comparison; firstly because the inclusion of omnivores such as chicken and pigs could introduce additional dietary biases that could further obscure the baseline for each site, secondly because the volume of omnivorous data was generally much poorer than data for herbivores. Although some of these comparative sites had relatively small datasets for herbivores (Ouvigo (Lopez-Costas, 2012), Trevino and Zornoztegi (Quiros Castillo, 2013) and Tomar (Curto et al., 2018)) or sometimes non-existant in the case of Tauste (Guede et al., 2017a), the data from omnivorous species was much more sparse (18 of the 30 sites had $<5$ omnivorous samples, mostly pigs). This is perhaps not too surprising, as extensive comparison of archaeozoological remains from Medieval Christian and Islamic sites (rural, urban, castles) revealed that sheep and goats were the most frequently found species, followed by cattle, whose numbers increased in urban sites (Grau-Sologestoa, 2017). Pigs, on the other hand, were found in much lower proportions in most sites studied by GrauSologestoa (2017) throughout the Middle Ages, though slightly higher in the 11th and 12th centuries at high-status sites where meat consumption was typically higher overall.

A list of the studies used for comparison within this paper is provided in Table 4 and the location of the Iberian sites is provided in Fig. 6. In order to remove the influence of geographic variation on stable carbon and nitrogen isotope values, the faunal (domestic herbivore) mean was subtracted from the human population mean for each population, thus only the $\delta^{13} \mathrm{C}$ and $\delta^{15} \mathrm{~N}$ dietary spacing are considered. These dietary spacing values are presented in Fig. 7 along with the expected range for a trophic level shift $\left(\delta^{13} \mathrm{C}=0-2 \%\right.$; $\delta^{15} \mathrm{~N}=3-5 \%$ ). Most of these populations fell within an expected +1 trophic level shift for $\delta^{15} \mathrm{~N}$ but there was more variability in $\delta^{13} \mathrm{C}$ values. The populations with $<3 \% \delta^{15} \mathrm{~N}$ spacing belonged to the low status/peasant/mixed rural populations of Aistra, Gozquez and Zornoztegi (Quiros Castillo, 2013; Garcia-Collado, 2016), so it is expected that they would not have had much access to meat in their diets. On the opposite end of the spectrum, the populations with the highest $\delta^{15} \mathrm{~N}$ and $\delta^{13} \mathrm{C}$ spacing ( $>6 \%$ and $>4 \%$ respectively) were from Pontevedra (Lopez-Costas, 2012), fishing communities whose diets relied heavily on marine fish rather than terrestrial fauna. When the sites are classified according to religious significance (i.e. monastic or convent populations, sites with possible aristocratic/clerical individuals and lay populations) a distinct pattern emerges. As Fig. 8 illustrates within the zone encircled in red, the sites of Aalst - a Carmelite friary (Quintelier et al., 2014), Dunes Abbey - a Late Medieval Cistercian order (Polet and Katzenberg, 2003), Rennes - a Dominican convent (Colleter et al., 2017), Tomar - a Templar site (Curto et al., 2018), San Pedro de Nora (MacKinnon, 2015) and Évora are clustered in the upper end of +1 trophic level $\delta^{15} \mathrm{~N}$ values ( 4 to $5 \%$ ) but their $\delta^{13} \mathrm{C}$ values are more than +1 trophic level ( 2 to $3 \%$ ) relative to the faunal values for each respective site.

Despite the different geographic locations and environments, whether coastal or inland, these sites display a dietary trend that is possibly related to strict religious fasting practices followed by these Christian populations. Many held high social status but were also expected to fast from meat periodically and may have consumed fish during this time, resulting in the slightly higher $\delta^{13} \mathrm{C}$ values. Furthermore, the Spanish sites of San Miguel de Lillo (MacKinnon, 2015) and Capela do Pilar (Lopez-Costas, 2012), both thought to have some association with nobility and/or clergy members, also seem to follow this trend. While most of these studies acknowledged the influence of fasting practices and input of marine fish on stable carbon and nitrogen isotope values (Polet and Katzenberg, 2003; Quintelier et al., 2014; Colleter et al., 2017), removing the faunal baseline (and thus geographic variation) and comparing the $\delta^{13} \mathrm{C}$ and $\delta^{15} \mathrm{~N}$ spacing for these populations makes this religiously-influenced dietary pattern all the more apparent. Overall, the fact that the Museu de Évora Christian population fits this dietary pattern could indicate that they were following religious rules 


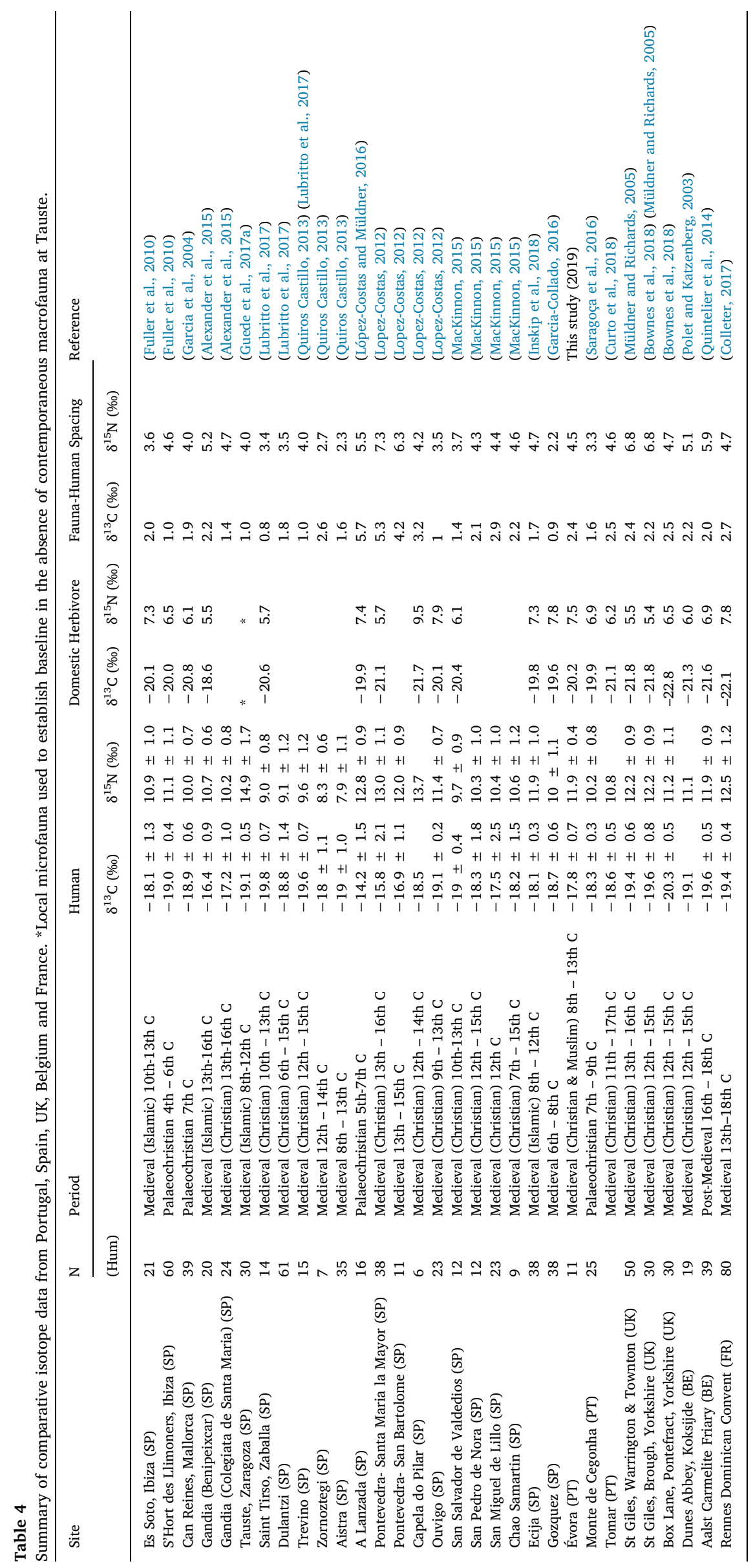




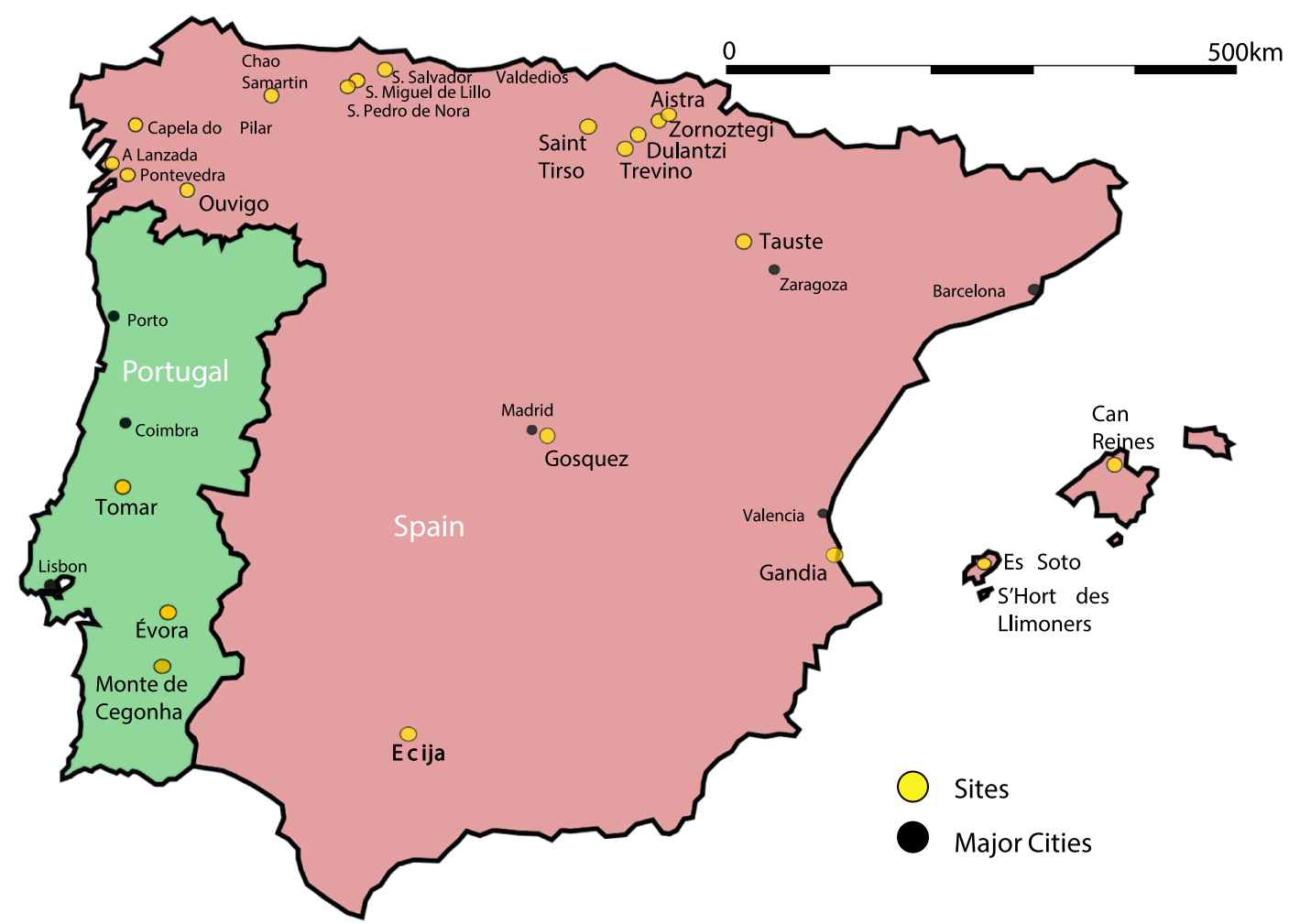

Fig. 6. Map of comparative sites from Iberia.

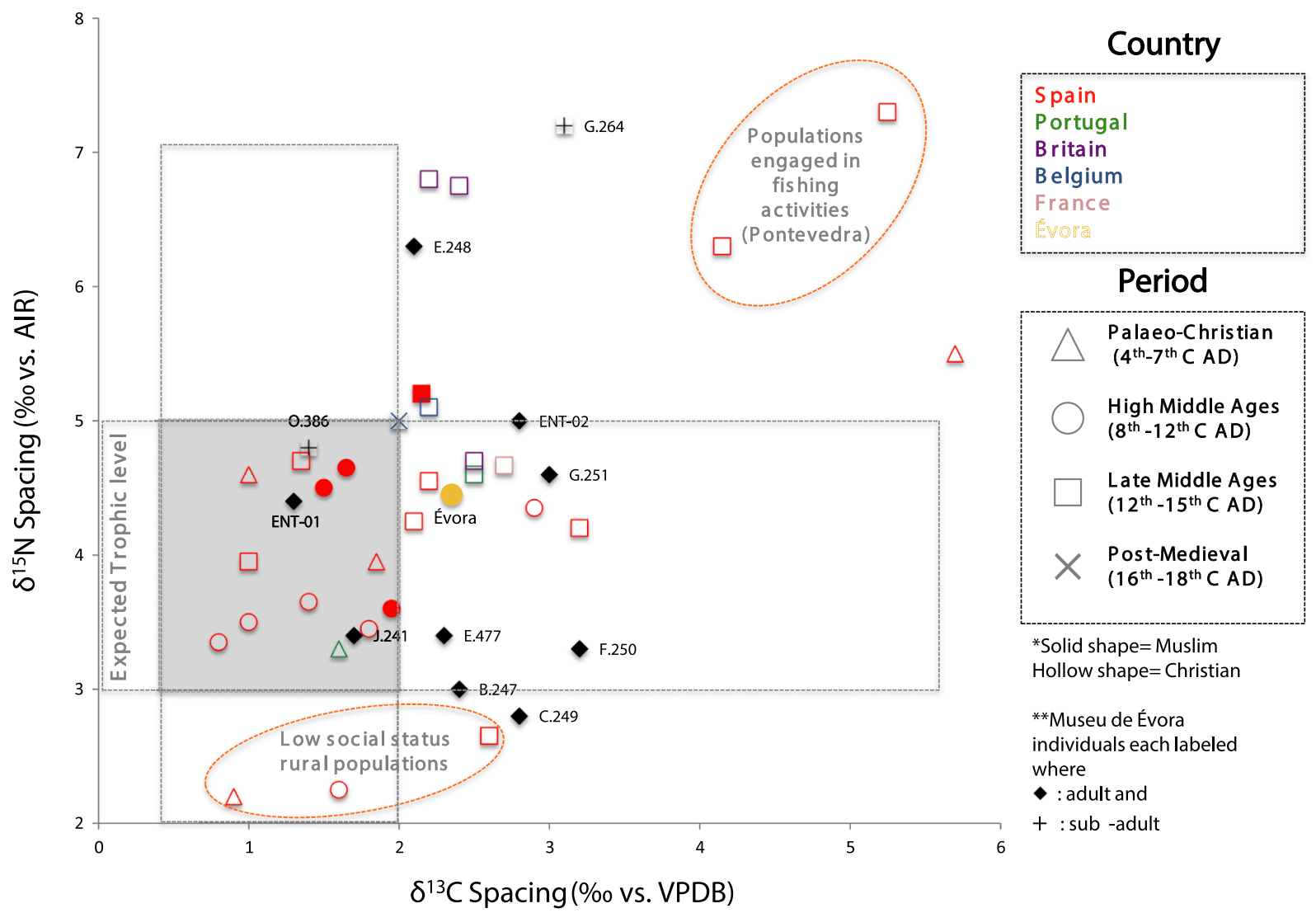

Fig. 7. Fauna to human $\delta^{13} \mathrm{C}$ and $\delta^{15} \mathrm{~N}$ spacing for comparative populations, calculated from the mean human and domestic herbivore isotopic values provide by each study (see full list in Table 4). Museu de Évora individuals represented by black diamond symbols. Shaded area represents expected spacing range for +1 trophic level. 


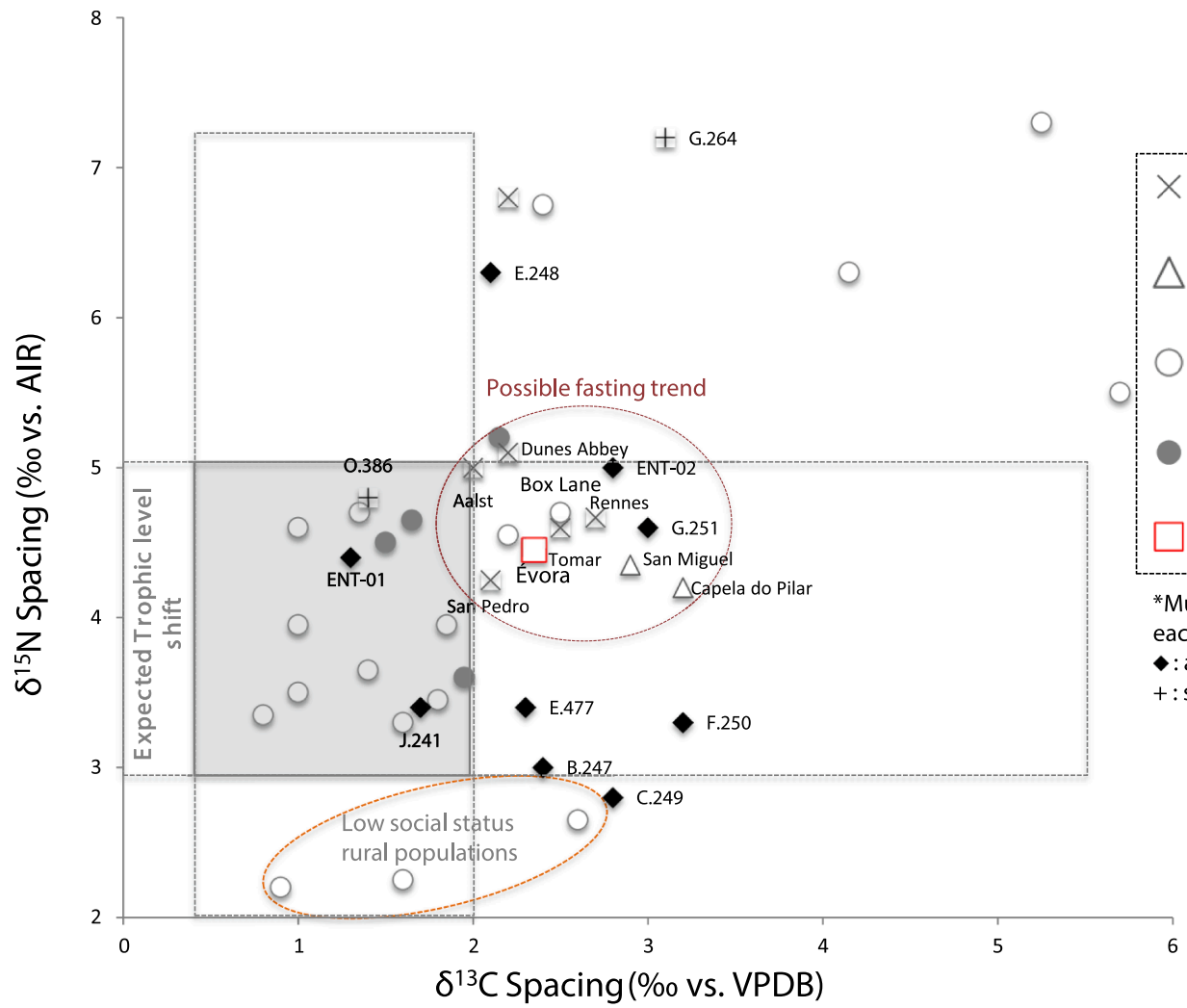

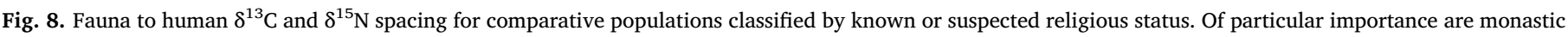
and convent populations, most of which are within the region circled in red.

that dictated meat-fasting and fish consumption, as long as they were in Évora for long enough for their bone collagen to adapt to their postarrival diet. It is also possible that some of these individuals were following the same dietary rules prior to arrival, if they belonged to other military-monastic communities such as the Order of Calatrava, but without knowing where precisely they came from, the use of local fauna from Évora gives the best approximation of terrestrial dietary input.

\section{Conclusion}

The use of multiple isotope systems can be a helpful tool to understand diet and mobility especially when used in conjunction with existing historical records and archaeological and anthropological evidence. In the case of the Museu de Évora skeletons, the use of stable carbon and nitrogen isotopes allowed for the reconstruction of a dietary pattern that is consistent with many studies of medieval monastic/religious communities across Europe and is also supported by historic documentation. This combined with the overall skeletal robustness and widespread traumatic injuries resulting from interpersonal violence provide strong evidence that these individuals did belong to the Évora Militia. In addition, stable oxygen and radiogenic strontium isotopes indicated that at least one young Christian was a local, suggesting that perhaps converts or local aristocracy were also welcomed into the Order, but this warrants further investigation. Most of the adult Christians were, however, non-local and in fact came from many different places, which sheds new light on the formation of the Order during the Christian conquest. The origins of the individuals were diverse geographically, but perhaps socially too, with access to different foods (grains) early in life as indicated by the enamel apatite carbon $\left(\delta^{13} \mathrm{C}_{\mathrm{en}}\right)$ values. The Order may not have arrived in Évora as a fully formed unit, but rather was made up of diverse individuals or smaller groups who saw the benefit in associating themselves with an Order that provided protection and social status. The privileges obtained through joining a military-monastic order during the conquest period would have undoubtedly been appealing to individuals from lower status families, at a time when social mobility was limited.

\section{CRediT authorship contribution statement}

Rebecca Anne MacRoberts: Conceptualization, Methodology, Formal analysis, Investigation, Writing - original draft, Writing - review \& editing, Visualization. Cristina Maria Barrocas Dias: Resources, Writing - review \& editing. Teresa Matos Fernandes: Resources, Writing - review \& editing. Ana Luisa Santos: Writing - review \& editing. Claudia Umbelino: Resources, Writing - review \& editing. Ana Gonçalves: Writing - review \& editing. Jose Santos: Validation, Investigation, Resources. Sara Ribeiro: Validation, Investigation, Resources. Bernd R. Schöne: Validation, Investigation, Resources, Writing - review \& editing. Filomena Barros: Resources. Fernando Correia: Resources. Herminia Vasconcelos Vilar: Resources, Writing review \& editing. Anne-France Maurer: Conceptualization, Methodology, Writing - original draft, Writing - review \& editing, Visualization, Supervision, Project administration, Funding acquisition.

\section{Acknowledgements}

This study is part of the research project TRANSCULTURAL: History, archaeology and anthropo-biogeochemistry of medieval populations in Portugal during the 10th-14th cent. AD. Culture identities and inter-culturality decoded via a dietary and mobility study (POCI01-0145-FEDER-031599) IC\&DT- AAC n. ${ }^{\circ}$ 02/SAICT/2017. This work was also supported by the Fundação para a Ciência e a Tecnologia FCT grant IF/01661/2015. The authors would like to thank Rodrigo Maia for sample preparation and S analysis at LIE-SIIAF, Cláudia Relvado for assistance with the anthropological material, and Cheila Ribeiro and Saskia Ammer for preparation of faunal samples. The authors would 
also like to express their gratitude to the two anonymous reviewers, whose helpful comments and suggestions greatly improved this manuscript.

\section{References}

Adamson, M.W., 2004. Food in medieval times. Greenwood Publishing, Connecticut. Alexander, M.M., Gerrard, C.M., Gutiérrez, A., Millard, A.R., 2015. Diet, society and economy in Late Medieval Spain: stable isotope evidence from Muslims and Christians from Gandia, Valencia. Am. J. Physical Anthropol. 1-11.

Ambrose, S.H., 1990. Preparation and characterization of bone and tooth collagen for isotopic analysis. J. Archaeol. Sci. 17, 431-451.

Ambrose, S.H., Norr, L., 1993. Experimental evidence for the relationship of the carbon isotope ratios for whole diet and dietary protein to those of bone collagen and carbonate. Springer, Berlin, pp. 1-37.

Ayala Martinez, C., 2003. Las Órdenes militares Hispánicas en la Edad Media (Siglos XIIXV). Marciel Pons Historia, Madrid.

Ayala, C., 2006. Order of Calatrava. In The Crusades, A. V. Murray. Santa Barbara, California: ABC-CLIO.

Balasse, M., 2002. Reconstructing dietary and environmental history from enamel isotopic analysis: time resolution of intra-tooth sequential sampling. Int. J. Osteoarchaeol, 12, 155-165.

Balasse, M., Ambrose, S.H., Smith, A.B., Price, T.D., 2002. The seasonal mobility model for prehistoric herders in the South-Western Cape of South Africa assessed by isotopic analysis of sheep tooth enamel. J. Archaeol. Sci. 29, 917-932.

Barata, F.T., Barros, M.F., Correia, F.B., Fernandes, H., Vilar, H.V., 2001. Elites sociais e apropriação do espaço no Além-Tejo na Idade Média. Ler Historia: Évora; Terras do sul etnografia e historia social.

Beirante, M.A., 1995. Évora na Idade Media. Fundação Calouste Gulbenkian: J.N.I.C.T., Lisbon.

Bentley, R.A., 2006. Strontium isotopes from the Earth to the archaeological skeleton: a review. J. Archaeol. Method Theory 13 (3), 135-187.

Bocherens, H., Drucker, D., 2003. Isotopic level enrichment of carbon and nitrogen in bone collagen: case studies from recent and ancient terrestrial ecosystems. Int. J. Osteoarchaeol. 13, 46-53.

Bowen, G.J., Wilkinson, B., 2002. Spatial disribution of delta O-18 in meteoric precipitation. Geology 30, 315-318.

Bownes, J., Clarke, L., Buckberry, J., 2018. The importance of animal baselines: using isotope analysis to compare diet in a British Medieval hospital and lay population. J. Archaeol. Sci. Rep. 17, 103-110.

Bronk Ramsey, C., 2009. Bayesian analysis of radiocarbon dates. Radiocarbon 51 (4), $337-360$.

Carvalhosa, A., 1983. Esquema geológico do Maciço de Évora. Comunicações dos Serviços Geológicos de Portugal 69, 201-208.

Chenery, C.A., Pashley, V., Lamb, A.L., Sloane, H.J., Evans, J.A., 2012. The oxygen isotope relationship between the phosphate and structural carbonate fractions of human bioapatite. Rapid Commun. Mass Spectrom. 26, 309-319.

Colleter, R., et al., 2017. Social status in late medieval and early modern Brittany: insights from stable isotope analysis. Archaeol. Anthropol. Sci. 1-15.

Conceicao, R., et al., 2018. Saharan dust transport to Europe and its impact on photovoltaic performance: a case study of soiling in Portugal. Sol. Energy 160, 94-102.

Coplen, T.B., 1988::. Normalization of oxygen and hydrogen isotope data. Chem. Geol. Isotope Geosci. Sect. 72, 293.

Cunha, M.C., 1988. Forais que tiveram por modelo o de Évora de 1166.

Cunha, M.C., 2009. Estudos sobre a Ordem de Avis (sécs XII-XV). Porto.

Curto, A, A-F Maurer, C Barrocas-Dias, P Mahoney, T Fernandes, and G Fahy. "Did military orders influence the general population diet? Stable isotope analysis from Medieval Tomar, Portugal.” Archaeological and Anthropological Sciences, 2018.

Darling, W.G., Talbot, J.C., 2003. The O \& H stable isotopic composition of fresh waters in the British Isles. Hydrol. Earth Syst. Sc. 7, 163-181.

Daux, V., Lecuye, C., Heran, M.A., Amiot, R., Simon, L., Fourel, F., Martineau, F., Lynneru, N., Reychler, H., Escarguel, G., 2008. Oxygen isotope fractionation between human phosphate and water revisited. J. Hum. Evol. 55, 1138-1147.

De Oliveira, P.M., 1956. A Milicia de Évora e a Ordem de Calatrava. Lusitania Sacra la Serie 1, 51-64.

DeNiro, M.J., 1985. Postmortem preservation and alteration of in vivo bone collagen isotope ratios in relation to palaeodietary reconstruction. Nature 317, 806-809.

DeNiro, M.J., Epstein, S., 1978. Influence of diet on the distribution of carbon isotopes in animals. Geochim. Cosmochim. Acta 42, 495-506.

DeNiro, M.J., Epstein, S., 1980. Influence of diet on the distribution of nitrogen isotopes in animals. Geochim. Cosmochim. Acta 45, 341-351.

Diaz-del-Rio, P., Thomas, A.J., Peate, D.W., Tykot, R.H., Martinez-Navarre, M.I., Vicent, J.M., 2017. Diet and mobility patterns in the Late Prehistory of Central Iberia (4000$1400 \mathrm{cal} \mathrm{BC})$ : the evidence of radiogenic $(87 \mathrm{Sr} / 86 \mathrm{Sr})$ and stable $(818 \mathrm{O}, \delta 13 \mathrm{C})$ isotopic ratios. Archaeol. Anthropol. Sci. 9, 1439-1452.

Evans, J.A., Chenery, C.A., Montgomery, J., 2012. A summary of strontium and oxygen isotope variation in archaeological human tooth enamel excavated from Britain. J. Anal. At. Spectrom. 27, 754-764.

Fahy, G.E., Deter, C., Pitfield, R., Miszkiewicz, J.J., Mahoney, P., 2017. Bone deep variation in stable isotope ratios and histomorphometric measurements of bone remodelling within adult humans. J. Archaeol. Sci. 10-16.

Faria, A.M., 2001. Pax Iulia, Felicitas Iulia, Liberalitas Iulia. Revista Portuguesa de Arqueologia (IPA) 4-2, 351-362.

Farwell, D., Molleson, T., 1993. Poundbury: The Cemeteries. Monogr. Series (Dorset
Natural History and Archaeological Society) 11.

Felipe, V.G. 2012. Contributo para o conhecimento da presença islâmica em Yàbura Estudo do espolio exumado nas intervenções arqueológicas do Museu Municipal de Évora. Master's Dissertation, Faculdade de Ciencas Sociais e Humanas, Universidade Nova de Lisboa, Lisbon.

Fogel, M.L., Tuross, N., Owsley, D.W., 1989. Nitrogen isotope tracers of human lactation in modern and archaeological populations. Yearb. Carnegie Institution Geophys. Laboratory 111-117.

Fuller, B.T., Marquez-Grant, N., Richards, M.P., 2010. Investigation of diachronic dietary patterns on the islands of Ibiza and Formentera, Spain: evidence from carbon and nitrogen stable isotope ratio analysis. Am. J. Phys. Anthropol. 143, 512-522.

Garcia, E., Subira, M.E., Richards, M.P., 2004. Diet and society through the analysis of Stable Isotopes: "Can Reines" example (Mallorca, Spain 600 AD). Antropo 7 , 171-176.

Garcia-Collado, M.I., 2016. Food consumption patterns and social inequality in an early medieval rural community in the centre of the Iberian Peninsula. In: J.A Quiros Castillo, Social complexity in Early Medieval rural communities: the North-Western Iberia archaeological record, 59-78. Oxford: Archaeopress Archaeology.

Gonçalves, A., Hauschild, T., Teichner, F. 1997. Intervenção Arqueológica no Museu de Évora, Centro Histórico de Évora, 1996. 3o Encontro de Arqueologia Urbana. Almada. Archaeological Report, Câmara Municipal de Almada, Évora.

Gonçalves, M.J., 2010. Novas problematicas relacionadas com a topografia da cidade islámica de Silves. Arqueologia Medieval (Edições Afrontamento).

Grau-Sologestoa, I., 2017. Socio-economic status and religious identity in Medieval Iberia: the zooarchaeological evidence. Environ. Archaeol. J. Human Palaeoecol. 22 (2), 189-199.

Guede, I., et al., 2017a. Isotope analyses to explore diet and mobility in a medieval Muslim population at Tauste (NE Spain). PLoS One 12 (5).

Guede, I., Ortega, L.A., Zuluaga, M.C., Alonso-Olazabal, A., Murelaga, X., Solaun, J.L., Sanchez, I., Azkarate, A., 2017b. Isotopic evidence for the reconstruction of diet and mobility during village formation in the Early Middle Ages: Las Gobas (Burgos, northern Spain). Archaeol. Anthropol. Sci.

Guerra, R., Fernandes, T., 2007. Relatório Antropologico: Museu de Évora. Anthropological Report, Laboratório de Antropologia Biológica, Universidade de Évora., Évora.

Hedges, R.E.M., Clement, J.G., Thomas, D.L., O'Connell, T.C., 2007. Collagen turnover in the adult femoral mid-shaft: modelled from anthropogenic radiocarbon tracer measurements. Am. J. Phys. Anthropol. 133, 808-816.

Hedges, R.E.M., Stevens, R.E., Koch, P.L., 2005. Isotopes in bones and teeth. In: M.J. Leng, Isotopes in Paleoenvironmental Research. Springer.

Hedges, R.E.M., Reynard, L.M., 2007. Nitrogen isotopes and the trophic level of humans in archaeology. J. Archaeol. Sci. 34, 1240-1251.

Hedges, R.E.M., Stevens, R.E., Richards, M.P., 2004. Bones as a stable isotope archive for local climatic information. Quart. Sci. Rev. 23, 959-965.

Humphrey, L.T., Dean, M.C., Jeffries, T.J., Penn, M., 2008. Unlocking evidence of early diet from tooth enamel. PNAS 10 (19), 6834-6839.

Iacumin, P., Bocherens, H., Mariotti, A., Longinelli, A., 1996. An isotopic palaeoenvironmental study of human skeletal remains from the Nile Valley. Palaeogeogr. Palaeoclimatol. Palaeoecol. 126, 15.

Inskip, S., Carroll, G., Waters-Rist, A., López-Costas, O., 2018. Diet and food strategies in a southern al-Andalusian urban environment during Caliph period, Écija, Sevilla. Archaeol. Anthropol. Sci.

International Atomic Energy Agency (IAEA)., 2018. WISER - Water Isotope System for data analysis, visualization and Electronic Retrieva. http://nucleus.iaea.org/wiser (accessed 20/08/2018)

Jiménez-Brobeil, S.A., Laffranchi, Z., Maroto, R.M., López-Sánchez, F.A., DelgadoHuertas, A., 2016. How royals feasted in the court of Pedro I of Castille: a contribution of stable isotope study to medieval history. J. Archaeolog. Sci. Rep. 10, 424-430.

Josserand, P., 2017. Élites et orders militaires au Moyen Âge: Recontre autor d'Alain Demurger. Casa de Velazquez, Madrid.

Josserand, P. "Order of Avis." In The Crusades, by A V Murray. Santa Barbara, California: ABC-CLIO, 2006

Kellner, C.M., Schoeninger, M.J., 2007. A simple carbon isotope model for reconstructing prehistoric human diet. Am. J. Phys. Anthropol. 113, 1112-1127.

Knipper, C. et al., 2015. Superior in life- Superior in death. Dietary distinction of Central European Prehistoric and Medieval elites. Curr. Anthropol.

Krouse, H.R., 1989. Sulfur isotope studies of the pedosphere and biosphere. In: K.A Nagy, Stable isotopes in ecological research. New York: Springer-Verlag.

Lamb, A.L., Evans, J.E., Buckley, R., Appleby, J., 2014. Multi-isotope analysis demonstrates significant lifestyle changes in King Richard III. J. Archaeol. Sci. 50, 559-565.

Lay, S., 2009. The Reconquest Kings of Portugal: Political and cultural reorientation on the Medieval frontier. Palgrave Macmillan, Hampshire.

Leach, S., Lewis, M., Chenery, C., Müldner, G., Eckardt, H., 2009. Migration and diversity in Roman Britain: a multidisciplinary approach to the identification of immigrants in Roman York, England. Am. J. Phys. Anthropol. 140, 546-561.

Lee-Thorp, J., 2008. On isotopes and old bones. Archaeometry 50.

Lee-Thorp, J.A., Sealy, J.C., van der Merwe, N.J., 1989. Stable carbon isotope ratio differences between bone collagen and bone apatite, and their relationship to diet. J. Archaeol. Sci. 6, 585-599.

Lightfoot, E., O'Connell, T.C., 2016. On the use of biomineral oxygen isotope data to identify human migrants in the archaeological record: intra-sample variation, statistical methods and geographical considerations. PLoS One 11 (4).

Loftus, E., Sealy, J., 2012. Technical note: Interpreting stable carbon isotopes in human tooth enamel: an examination of tissue spacings from South Africa. Am. J. Phys Anthropol. 147, 499-507.

Longin, R., 1971. New method of collagen extraction for radiocarbon dating. Nature 230, 
241-242.

López-Costas, O., Müldner, G., 2016. Fringes of the empire: Diet and cultural change at the Roman to post-Roman transition in NW Iberia. Am. J. Phys. Anthropol. 161, 141-154.

Lopez-Costas, O., 2012. Antropologia de los restos oseos humanos de Galicia: Estudio de la poblacion romana y medieval gallega. Doctoral Thesis, Programa Oficial de Posgrado en Evolucion Humana, Antropologia Fisica y Forense, Universidad de Granada, Universidad de Granada.

Lubritto, C., Garcia-Collado, M., Ricci, P., Altieri, S., Sirignano, C., Quiros Castillo, J.A., 2017. New dietary evidence on medieval rural communities of the Basque country (Spain) and its surroundings from carbon and nitrogen stable isotope analyses: Social insights, diachronic changes and geographic comparison. Int. J. Osteoarchaeol. 27, 984-1002.

Luxton, S A. Exploring the relationship between diet and osteoporosis in Medieval Portugal using stable isotope analysis. Master's Dissertation, University of Alaska Fairbank, Fairbank, 2015

MacKinnon, A.T., Passalacqua, N.V., Bartelink, E.J., 2019. Exploring diet and status in the Medieval and Modern periods of Asturias, Spain, using stable isotopes from bone collagen. Archaeol. Anthropol. Sci.

MacKinnon, A.T., 2015. Dietary reconstruction of Medieval and Early Modern Spanish populations using stable isotopes of carbon and nitrogen. Masters Thesis, Anthropology, California State University, Chico: California State University, 2015

Mafart, B., Pelletier, J.-P., Fixot, M., 2004. Post-mortem ablation of the heart: a medieval funerary practice. A case observed at the cemetery of Ganagobie priory in the French department of Alpes de Haute Provence. Int. J. Osteoarchaeol. 14, 67-73.

Makarewicz, C.A., Sealy, J., 2015. Dietary reconstruction, mobility and the analysis of ancient skeletal tissues: expanding the prospects of stable isotope research in archaeology. J. Archaeol. Sci. 56, 146-158.

Malainey, M.E., 2010. A consumer's guide to archaeological science: Analytical techniques. Springer Science \& Business Media, Berlin.

Marques, A.H.R.O., 1987. The Portuguese Medieval society: aspects of everyday life. Sá da Costa, Lisbon.

Marquez, A.H.R.O., 1971. Daily life in Portugal in the Late Middle Ages. University of Wisconsin Press, Madison, Wisconsin.

Mays, S.A., 1997. Carbon stable isotope ratios in medieval and later human skeletons from Northern England. J. Archaeol. Sci. 24, 561-567.

Metcalfe, J.Z., Longstaffe, F.J., White, C.D., 2009::. Method-dependent variations in stable isotope results for structural carbonate in bone bioapatite. J. Archaeol. Sci. 36, 110.

Moita, P., Santos, J.F., Pereira, M.F., 2009. Layered granitoids: interaction between continental crust recycling processes and mantle-derived magmatism. Lithos 111, $125-141$.

Moita, P., Santos, J.F., Pereira, M.F., Costa, M.M., Corfu, F., 2015. The quartz-dioritic Hospitais intrusion (sw Iberian Massif) and its mafic microgranular enclaves - evidence for mineral clustering. Lithos 224-225, 78-100.

Montgomery, J., Evans, J.A., Neighbour, T., 2003. Sr isotope evidence for population movement within the Hebridean Norse community of NW Scotland. J. Geol. Soc. 160, 649-653.

Müldner, G., Richards, M.P., 2005. Fast or feast: reconstructing diet in later medieval England by stable isotope analysis. J. Archaeol. Sci. 32, 39-48.

Navarro Palazón, J., Jiménez Castillo, P., 2007. Evolución del paisaje urbano andalusí de la Medina dispersa a la saturada. In F.R. Castro, Paisaje y naturaleza en al-Andalus. Ayuntamiento de Madrid. Madrid.

Nehlich, O., 2015. he application of sulphur isotope analysis in archaeological research: a review. Earth Sci. Rev. 142, 1-17.

Nehlich, O., Richards, M.P., 2009. Establishing collagen quality criteria for sulphur isotope analysis for archaeological bone collagen. Archaeol. Anthropol. Sci. 1, 59-75.

Nehlich, O., Borić, D., Stefanović, S., Richards, M.P., 2010. Sulphur isotope evidence for freshwater fish consumption: a case study from the Danube Gorges, SE Europe. J. Archaeol. Sci. 37, 1131-1139.

Nehlich, O., Fuller, B.T., Marquez-Grant, N., Richards, M.P., 2012. Investigation of diachronic dietary patterns on the islands of Ibiza and Formentera, Spain: evidence from sulfur stable isotope ratio analysis. Am. J. Phys. Anthropol. 149 (1), 115-124.

O'Leary, Marion H., 1988. Carbon isotopes in photosynthesis. Bioscience 38 (5), 328-336. https://doi.org/10.2307/1310735.

Palfi, G., Dutour, O., 1995. Informations sur les activités du passé apportées par le squelette. Dossier d'Archaeologie 208, 11-21.

Paredes, X.M., 2001. Cultural differences in Portugal: the origins of the country. University College Cork, Cork.

Passey, B.H., et al., 2005. Carbon isotope fractionation between diet, breath $\mathrm{CO} 2$ and bioapatite in different mammals. J. Archaeol. Sci. 32, 1459-1470.

Pederzani, S., Britton, K., 2019. Oxygen isotopes in bioarchaeology: Principles and applications, challenges and opportunities. Earth Sci. Rev. 188, 77-107.

Pellegrini, M., Lee-Thorp, J.A., Donahue, R.E., 2011. Exploring the variation of the $\delta^{18} \mathrm{O}_{\mathrm{p}}$ and $\delta^{18} \mathrm{O}_{\mathrm{c}}$ relationship in enamel increments. Palaeogeogr. Palaeoclimatol. Palaeoecol. 310, 71-83.

Peterson, B.J., Fry, B., 1987. Stable isotopes in ecosystem studies. Annu. Rev. Ecol. Syst. $18,293-320$

Picard, C., 2000. Le Portugal musulman (VIIIe-XIIIe siècle). L'Occident d'al-Andalus sous domination islamique. Maisonneuve et Larose, Paris.

Pizarro, J.A.S.M., 2006. The participation of the nobility in the reconquest and in the military orders. E-JPH 4, no. 1.

Polet, C., Katzenberg, M.A., 2003. Reconstruction of the diet in a medieval monastic community from the coast of Belgium. J. Archaeol. Sci. 30, 525-533.

Pollard, A.M., Ditchfield, P., Piva, E., Wallis, S., Falys, C., Ford, S., 2012. Sprouting like like cockle amongst the wheat: the St Brice's Day massacre and the isotopic analysis of human bones from St John's College, Oxford. Oxford J. Archaeol. 32, 83-102.
Price, T.D., Burton, J.H., Bentley, R.H., 2002. The characterization of biologically available strontium isotope ratios for the study of prehistoric migration. Archaeometry 44 (1), 117-135.

Price, T.D., Gestsdóttir, H., 2006. The first settlers of Iceland: an isotopic approach to colonization. Antiquity 80, 130-144.

Privat, K.L., O'Connell, T.C., Hedges, R.E.M., 2007. The distinction between freshwaterand terrestrial-based diets: methodological concerns and archaeological applications of sulphur stable isotope analysis. J. Archaeol. Sci. 34, 1197-1204.

Pryor, J.E.A., Stevens, R.E., O'Connell, T., Lister, J.R., 2014. Quantification and propagation of errors when converting vertebrate biomineral oxygen isotope data to temperature for paleoclimate reconstruction. Palaeogeogr. Palaeoclimatol. Palaeoecol. 412, 99-107.

Quintelier, K., et al., 2014. Isotopic examination of the links between diet, social differentiation and DISH at the Post Medieval Carmelite Friary of Aalst, Belgium. Am. J. Phys. Anthropol. 153, 203-213.

Quiros Castillo, J.A., 2013. Los comportamientos alimentarios del campesinado medieval en el Pais Vasco y su entorno (siglos VIII-XIV). Hist. Agrar 59, 13-41.

Rao, Z.G., Chen, F.H., Zhang, X., 2012. Spatial and temporal variations of C3/C4 relative abundance in global terrestrial ecosystem since the Last Glacial and it's possible driving mechanisms. Chin. Sci. Bull. 57, 4024-4035.

Rei, A., 2005. O Gharb al-Andalus em dois geógrafos árabes do século VII/XII: Yâqût alHamâwî e Ibn Sa'îd al-Maghribî. Medievalista 1.

Reid, D.J., Dean, M.C., 2006. Variation in modern human enamel formation times. J. Hum. Evol. 50 (3), 329-346.

Reimer, P.J., Bard, E., Bayliss, A., Beck, J.W., Blackwell, P.G., Bronk Ramsey, C., Buck, C.E., Cheng, H., Edwards, R.L., Friedrich, M., Grootes, P.M., Guilderson, T.P., Haflidason, H., Hajdas, I., Hatté, C., Heaton, T.J., Hoffman, D.L., Hogg, A.G., Hughen, K.A., Kaiser, K.F., Kromer, B., Manning, S.W., Niu, M., Reimer, R.W., Scott, E.M., Richards, D.A., Southon, J.R., Staff, R.A., Turney, C.S.M., van der Plicht, J., 2013. IntCal13 and Marine13 radiocarbon age calibration curves 0-50,000 years cal BP. Radiocarbon 55 (4), 1869-1887.

Ribeiro, O., 1994. Opúsculos Geográficos - Temas Urbanos. Fundação Calouste Gulbenkian.

Richards, M.P., Fuller, B.T., Sponheimer, M., Robinson, T., Ayliffe, L., 2003. Sulphur isotopes in palaeodietary studies: a review and results from a controlled feeding experiment. Int. J. Osteoarchaeol. 13, 37-45.

Roca, Z., Oliveira, J.A., 2005. A paisagem como elemento da identidade e recurso para o desenvolvimento. Congresso Ibérico da Geografia. Évora.

Rodriguez-Navarro, C., di Lorenzo, F., Elert, K., 2018. Mineralogy and physicochemical features of Saharan dust wet deposited in the Iberian Peninsula during an extreme red rain event. Atmos. Chem. Phys 18, 10089-10122.

Rozanski, K., Araguas-Araguas, L., Gonfiantini, R., 1993. Isotopic patterns in modern global precipitation. Geophysical Monogr. 78, 1-36.

Santos, A.L., Umbelino, C., 1997. Museu de Évora- Dados antropologicos sobre o passado medieval e muçulmano. Os Militares da Reconquista Cristã. Anthropological Report, Laboratorio de paleodemografia e Paleopatologia- Departamento de Antropologia, Universidade de Coimbra, Coimbra.

Santos, A.L., Umbelino, C., Gonçalves, A., Pereira, F.D., 1998. Mortal combat during the Medieval Christian Reconquest in Evora, Portugal. Int. J. Osteoarchaeol. 8, 454-456.

Santos, A.L., Umbelino, C., 2007. "Os militares de Reconquista Cristã: Dados antropológicos sobre o passado medieval e muçulmano de Évora”. [Relatório]. Cenáculo. Boletin online do Museu de Évora 2, 1-16.

Saragoça, P., et al., 2016. Stable isotope and multi-analytical investigation of Monte de Cegonha; a late antiquity population in Southern Portugal. J. Archaeolog. Sci.: Rep. 9, 728-742.

Scheeres, M., Knipper, C., Hauschild, M., Schönfelder, M., Siebel, W., Pare, C., Alt, K.W., 2014. "Celtic Migrations": fact or fiction? Strontium and oxygen isotope analysis of the Czech cemeteries of Radovesice and Kutná Hora in Bohemia. Am. J. Physical Anthropol. 155 (4), 496-512.

Schoeninger, M.J., DeNiro, M.J., 1983. Nitrogen and carbon isotopic composition of bone collagen from marine and terrestrial animals. Geochim. Cosmochim. Acta 48, 625-639.

Schoeninger, M.J., DeNiro, M.J., Tauber, H., 1983. Stable nitrogen isotope ratios of bone collagen reflect marine and terrestrial components of prehistoric human diet. Sci. New Series 220 (4604), 1381-1383.

Schoeninger, M.J., Moore, K., 1992. Bone stable isotopes in archaeology. J. World Prehistory 6 (2).

Sealy, Judith, Johnson, Malia, Richards, Michael, Nehlich, Olaf, 2014. Comparison of two methods of extracting bone collagen for stable carbon and nitrogen isotope analysis: comparing whole bone demineralization with gelatinization and ultrafiltration. J. Archaeol. Sci. 47, 64-69. https://doi.org/10.1016/j.jas.2014.04.011.

Sealy, J.C., van der Merwe, N.J., 1986. Isotope assessment and the seasonal mobility hypothesis in the Southwestern Cape of South Africa. Curr. Anthropol. 27 (2).

Sealy, J.C., van der Merwe, N.J., Lee-Thorp, J.A., Lanham, J.L., 1987. Nitrogen isotope ecology in Southern Africa: implications for environmental and dietary tracing. Geochim. Cosmochim. Acta 51, 2707-2717.

Sharp, Z.D., 2007. Principles of stable isotope geochemistry. Prentice Hall, New Jersey.

Shaw, H., Montgomery, J., Redfern, R., Gowland, R., Evans, J., 2016. Identifying migrants in London using lead and strontium stable isotopes. J. Archaeol. Sci. 66, 57-68.

Sidarus, A., 1997. Novas perspectivas sobre o Gharb al-Ândalus no tempo de D. Afonso Henriques. Actas do 2o Congresso Histórico de Guimarães 249-268.

Simon, G.A., 2009. Commentary for Benedictine Oblates: On the rule of St Benedict. Translated by L.J. Doyle. Oregon: Wipf \& Stock Publishers.

Smith, B.H., 1991. Standards of human tooth formation and dental age assessment. Adv. Dental Anthropol. 8, 143-168.

Sponheimer, M., Lee-Thorp, J.A., 1999. Oxygen isotopes in enamel carbonate and their 
ecological significance. J. Archaeol. Sci. 26, 723-728.

Tarouca, C.S., 1947. As origens da ordem dos cavaleiros de Évora (Avis) segundo as cartas do Arquivo do Cabildo da Sé de Évora. A Cidade de Évora 1, 25-39.

Tobias, L.C.N.S.V., 2013/ Caraterização de Aerossóis de Évora. Masters Thesis, Department of Chemistry, University of Evora, Évora: University of Evora.

Torres, C., Macias, S., 1995. Rituais funerários paleocristãos e islâmicos nas necropolis de Mértola. In: C. Torres, S. Macias, O reino dos mortos na Idade Media Peninsular. Lisbon: Joao Sa da Costa.

Toso, A., Gaspar, S., da Silva, R.B., Garcia, S.J., Alexander, M., 2019. High status diet and health in Medieval Lisbon: a combined isotopic and osteological analysis of the Islamic population from São Jorge Castle, Portugal. Archaeol. Anthropol. Sci. 1-18.

Tütken, T., Langenegger, E., Wild, W., 2008:.: Native or not? Isotope analysis of a female skeleton on the $9^{\text {th }}$ century AD from Elsau, Canton Zurich, Switzerland. Anthropol. Anz. 66, 19.
Vogel, J.C., 1980. Fractionation of carbon isotopes during photosynthesis. SpringerVerlag, Berlin Heidelberg.

Vogel, J.C., van der Merwe, N.J., 1978. Isotopic evidence for early maize cultivation in New York State. Am. Antiq. 24, 238-242.

Waterman, A.J., Peate, D.W., Silva, A.M., Thomas, J.T., 2014. In search of homelands: using strontium isotopes to identify biological markers of mobility in late prehistoric Portugal. J. Archaeol. Sci. 42, 119-127.

Wolfe, M., 1999. The medieval city under siege. Boydell \& Brewer, Suffolk.

Wright, L.E., Schwarcz, H.P., 1998. Stable carbon and oxygen isotopes in human tooth enamel: identifying breastfeeding and weaning in prehistory. Am. J. Physical Anthropol. 106 (1), 1-18.

Zalaitè, I., Maurer, A.-F., Grimes, V., Silva, A.M., Ribeiro, S., Santos, J.F., Barrocas Dias, C., Valera, A.C., 2018. Diet and mobility of fauna from the Late Neolithic-Chalcolithic site of Perdigões, Portugal. J. Archaeol. Sci. Rep. 19, 674-685. 